
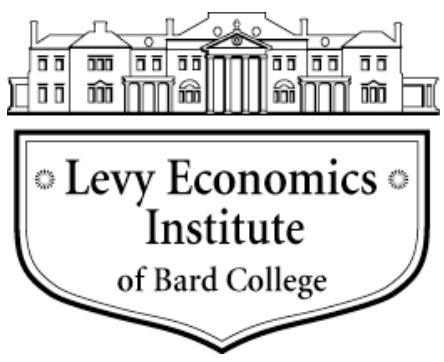

Working Paper No. 726

\title{
Time Use of Mothers and Fathers in Hard Times: The US Recession of 2007-09
}

by

Günseli Berik

University of Utah

Ebru Kongar*

Dickinson College

June 2012

* Authors’ e-mails, respectively: berik@economics.utah.edu, kongare@dickinson.edu

The Levy Economics Institute Working Paper Collection presents research in progress by Levy Institute scholars and conference participants. The purpose of the series is to disseminate ideas to and elicit comments from academics and professionals.

Levy Economics Institute of Bard College, founded in 1986, is a nonprofit, nonpartisan, independently funded research organization devoted to public service. Through scholarship and economic research it generates viable, effective public policy responses to important economic problems that profoundly affect the quality of life in the United States and abroad.

\author{
Levy Economics Institute \\ P.O. Box 5000 \\ Annandale-on-Hudson, NY 12504-5000 \\ http://www.levyinstitute.org
}

Copyright (C) Levy Economics Institute 2012 All rights reserved

ISSN 1547-366X 


\begin{abstract}
The recession precipitated by the US financial crisis of 2007 accelerated the convergence of women's and men's employment rates, as men experienced disproportionate job losses and women's entry into the labor force gathered pace. Using the American Time Use Survey (ATUS) data for 2003-10, this study examines whether the recession also occasioned a decline in disparity in unpaid work burdens and provided impetus for overall progress toward equity in the workloads, leisure time, and personal care hours of mothers and fathers. Controlling for the prerecession trends, we find that the recession contributed to the convergence of both paid and unpaid work only during the December 2007-June 2009 period. The combined effect of the recession and the jobless recovery was a move toward equity in the paid work hours of mothers and fathers, a relative increase in the total workload of mothers, and a relative decline in their personal care and leisure time.
\end{abstract}

Keywords: Economics of Gender; Unemployment; Time Use; Economic Crises JEL Classifications: D13, J16, J22, J64 


\section{INTRODUCTION}

In December 2007, the US economy entered the longest and the deepest economic downturn since the Great Depression. Between 2007 and 2009, the average unemployment rate doubled, increasing from 4.6 percent in 2007 to 9.3 percent in 2009 . While the recession officially ended in June 2009, job losses continued until the end of the year, and the unemployment rate continued at 9.6 percent in 2010 (Bureau of Labor Statistics [BLS] 2010a). Initially, job losses came disproportionately for men as the male-dominated manufacturing and construction sectors were hit harder. In the face of high male unemployment, married women entered the labor force to supplement family income (Şahin, Song, and Hobijn 2010). Among them, mothers with children experienced the largest increase in their participation rate between 2007 and 2009 (BLS 2011). As a result, women's share of paid employment, which had been relatively stagnant since the 1990s, reached the 50 percent threshold for the first time in US history in 2009 (Institute for Women's Policy Research [IWPR] 2011a). ${ }^{1}$ Using the American Time Use Survey (ATUS) data, this study examines whether the recession also occasioned a decline in disparity in unpaid work burden and overall progress toward equity in the workloads, leisure time, and personal care hours between mothers and fathers.

The long-term trend in unpaid childcare and housework in the US has been one of gender convergence. Between 1965 and 2003, the gender difference in unpaid work hours narrowed as men spent more time on unpaid work and women spent less (Bianchi, Robinson, and Milkie 2006; Blau and Kahn 2007). However, progress in unpaid work was much slower compared to paid work, and stalled as of the early 2000s, when women continued to take on a disproportionate share of unpaid work (Bianchi, Robinson, and Milkie 2006; Guryan, Hurst, and Kearney 2008; Sayer 2005).

Only a few studies have analyzed the recession's effect on time use and the relationship between unemployment, the post financial crisis recession, and unpaid work hours in the US economy (Aguiar, Hurst, and Karabarbounis 2011; Morrill and Pabilonia 2012). While the effect of macroeconomic conditions on individuals' allocation of time between unpaid work and leisure has been a longstanding question in the macroeconomic literature, its empirical testing for the US has become possible only recently, as time use data from the ATUS became available over a business cycle. The emerging literature indicates that men and women allocated roughly equal proportions of their foregone hours to unpaid work and leisure during the post-2008 
recession (Aguiar, Hurst, and Karabarbounis 2011). Unemployment contributed to greater sharing of childcare as fathers increased their childcare time while mothers did not reduce theirs (Morrill and Pabilonia 2012). There was also a narrowing of the gap in unpaid labor of mothers and fathers, which widened again after the end of the recession in June 2009 (Berik and Kongar 2011). Berik and Kongar (2011) traced this pattern to the changes in the gender difference in housework hours, which narrowed during the recession and stalled during recovery.

The recession precipitated by the 2007 financial crisis was unusual in its intensity and in its prolonged nature. It also hit at a moment in US history when there seemed to be no more room for mothers to reduce their unpaid hours and for fathers to take on additional unpaid work. This combination provides the possibility for new gender patterns of time use to emerge and settle in. This paper examines the effect of the recession on the trends under way in paid and unpaid work hours and total workload of mothers and fathers, and in turn, their time for leisure and personal care activities. We examine the "iso-work" argument, according to which, in a number of affluent countries, including the US, women and men have attained parity in total workload, even as women and men perform different tasks (Burda, Hamermesh, and Weil 2012). The iso-work argument suggests, and indeed seems to find support in the BLS evidence for 2010, that the disproportionate total work burden borne by employed women may be a thing of the past (BLS 2010b; Konigsberg 2011).

Our focus is on married mothers and fathers. We use individual-level monthly data from the 2003-2010 American Time Use Survey (ATUS). The sample consists of women and men in the 18-65 age group who live in the same household with their spouse and at least one child under the age of $18 .^{2}$ These mothers and fathers are not married to each other. In the ATUS methodology it is not possible to directly obtain information on the time use of the partner of the respondent and hence to examine the gender division of labor and hours in the household in a satisfactory manner. ${ }^{3}$

Our goal is to produce a gender-aware account of the effect of the recession precipitated by the 2007 crisis. We examine separately for mothers and fathers how the time spent in unpaid work, personal care and leisure activities varied prior to and during the recession, and after its official end, and how these changes altered the relative time use of mothers and fathers. One issue relevant to this analysis is to determine whether the observed changes are the ones that would have occurred in the absence of the recession. This is a methodological weakness of Berik and Kongar (2011), who use ANOVA without controlling for trends to examine the 
gender-differentiated effects of the recession on time use. Thus, based on ATUS data for the period prior to the recession, we differentiate between the trend and the cycle to ascertain the effect of the recession over and above the long-term trends in time use.

The proper dating of the latest US recession presents a challenge since unemployment rates continued to rise for both women and men after the National Bureau of Economic Research (NBER) declared the recession over in June 2009. Time allocation between paid and unpaid work and among various unpaid tasks and non-work activities is clearly contingent on the changes in the employment status of ATUS respondents over the cycle. Thus, while we adopt the NBER dating for the recession (as the December 2007-June 2009 period) we use as a sensitivity check the intensity of job losses to date the recession period as January 2009 December 2010.

Controlling for the pre-recessionary trends in time use of mothers and fathers, we establish that the recession contributed to the convergence in their paid work through the increase in paid work of mothers and decline in paid work of fathers. This recession effect held regardless of how the recession is dated and how the sample of mothers and fathers is defined. The difference in unpaid hours also narrowed, in this case mainly through the decline in unpaid work done by mothers. However, the recession's effect on unpaid work held only when the recession is dated according to the NBER approach and disappeared during the jobless recovery after June 2009. In fact, there was a weak reversal in the effect of the recession on unpaid labor during the extended unemployment period. Had the pre-recessionary trends continued, the gap in unpaid work would have narrowed during this period, instead it widened slightly. This result indicates that the reversal of the changes in the unpaid work gap in Berik and Kongar (2011) was attributable to the recession, rather than the continuation of pre-recession trends.

When the combined effect of the recession and jobless recovery (between December 2007 and December 2010) is considered, again, the recession contributed to a considerable narrowing in the paid hours of mothers and fathers. This effect was accompanied by a smaller and statistically weaker narrowing of the gap in unpaid work hours. As a result, relative to mothers, the recession brought decline in fathers' total workload and rise in their relative leisure time, owing to the increase in leisure time for fathers. These results indicate that the recession did not generate pressures for more equitable sharing of workload by mothers and fathers. 


\section{BACKGROUND}

\section{Trends in Time Use}

Prior to the financial crisis of 2007, there was a substantial convergence in women's and men's market work in the US as a result of trends under way since at least the 1970s. This convergence was driven primarily by women's entry into the labor force and an increase in their paid work hours. ${ }^{4}$ Married mothers, including mothers with young children, were on the forefront of the rise in women's market participation, registering the largest increases in both labor force participation and paid hours. ${ }^{5}$ Time diary data for the 1975-2000 period show that the difference between mothers' and fathers' paid work hours narrowed by 9 hours per week, primarily due to an increase in mothers' paid work hours (Bianchi, Wight, and Raley 2005). As the time mothers and fathers spent at paid work became similar, so did their unpaid work hours: during this period the difference between mothers' and fathers' weekly unpaid work hours declined by 11.5 hours as fathers increased their unpaid work by 9.6 hours and mothers reduced theirs by 1.9 hours.

Mothers appear to have "financed" the increase in their paid work hours by reducing their housework, but seem to have protected their childcare time, even increasing it after 1985, while fathers increased their time initially in housework and gradually in childcare (Bianchi, Robinson, and Milkie 2006; Ramey and Francis 2009). Mothers whose paid work hours increased also had considerably less time for leisure and personal care (Bianchi et al. 2000; Howie et al. 2006; Sandberg and Hofferth 2001).

Much of the gender convergence in market work occurred prior to 1990. In the early 2000s there was little change in either the labor force participation gap or the paid hours gap. ${ }^{6}$ Between 2000 and 2006, mothers' labor force participation actually declined from 70.9 percent to 68.5 percent, with a larger decline in labor force participation among mothers of children under the age of six.

The slower convergence in paid work hours in the 1990s was accompanied by a slowdown in convergence in unpaid work hours. In the post-1985 period, the only movement in housework was a slight decline in mothers' housework hours (Blau and Kahn 2007; Ramey 2008; Aguiar and Hurst 2007). Over the same period, there was also little change in childcare, as fathers and mothers increased their childcare hours by about the same amount. The ATUS data for the pre-recessionary 2003-06 period show that relative to fathers, mothers' paid work hours 
increased by only 0.4 hours, while their childcare and housework declined by 0.3 hours and 0.1 hours, respectively (Bianchi 2011).

Cross-sectional studies based on ATUS data show inequalities in childcare hours regardless of employment status. In the 2003-06 period, mothers spent more hours caring for children than fathers did (Guryan, Hurst, and Kearney 2008). The gender gap was larger among the mothers and fathers who were not working for pay, suggesting that the gender difference reflects more than relative time constraints brought by paid work hours. Cross-sectional analyses of variation in time use by individual and household characteristics have similarly confirmed that, regardless of employment status, mothers spend more time than fathers on housework (Bianchi, Wight, and Raley 2005; Hartmann, English, and Hayes 2010).

Underlying the gender differences in the aggregate patterns of time-use are linkages between labor markets, gender norms and the institutional and historical setting. The slowdown in the convergence in unpaid work hours since the mid-1980s, for example, has been traced to the persistence of gender inequitable norms with respect to childcare and housework (Rones, Ilg, and Gardner 1997; Sayer, Cohen, and Casper 2004). While it became more acceptable for women to adopt the traditionally masculine behavior of breadwinning, men have been slow to adopt the feminine behavior of doing unpaid work, possibly because of its devaluation (Coltrane 2000; Risman 1998). Surveys of attitudes suggest greater adaptability of fathers in taking on childcare compared to housework (Boushey and O'Leary 2009; Coltrane 2000). The attitudes toward housework remain more in conformity with the traditional gender division of labor, whereby women who are in the labor force are expected to take on more responsibilities for the home and family than their male partners. Gender asymmetric norms regarding motherhood are also expressed in the anxiety about the ability of employed mothers to be good mothers (Boushey and O'Leary 2009). Mothers' desire to conform to the ideal of motherhood may explain their tendency to protect childcare time in the face of increasing paid work hours (Hays 1996; BlairLoy 2003).

A number of studies have argued that further progress toward gender parity in paid and unpaid work is unlikely without moving away from the "male" model of employment (with long work weeks) and having childcare centers open for longer hours (Boushey and O'Leary 2009; Jacobs and Gerson 2004; Williams 2000). In the absence of more gender equitable sharing of unpaid and paid work and relaxation of institutional constraints on work-family balance, women's, especially mothers', ability to balance work responsibilities inside and outside of the 
home may have finally reached a limit. Slow progress on the paid work front is also attributed to persistent gender inequalities in the US labor markets, in particular, the stagnant gender pay gap despite improvements in women's educational attainment and experience since the mid-1990s (Blau and Kahn 2007), and the persistence of a glass ceiling for highly educated women with work experience (US General Accounting Office 2001).

The emphasis on gender disparity in workloads in much of this literature is challenged by the iso-work argument of Burda, Hamermesh, and Weil (2012). They argue that while women and men differ in how they allocate their time between unpaid and paid work, the total hours each spends working have reached parity in the first decade of the $20^{\text {th }}$ century. While the iso-work argument has been put forth as valid in downturns as well as in non-recession times, a stronger test for it would be for similarly situated groups, such as full-time mothers and fathers. The BLS data for 2010 suggest an emerging parity for precisely these groups, which has received attention in the US popular press (Konigsberg 2011). ${ }^{7}$ Our study will examine the iso-work argument to ascertain the trends in total work burden of mothers and fathers prior to the recession and the effect of the recession on these trends.

\section{The Effect of the Business Cycle on Time Use}

Macroeconomic theory has long predicted household production to increase during recessions as households substitute home-produced goods and services for market purchases (Benhabib, Rogerson, and Wright 1991; Greenwood and Hercowitz 1991). Only recently has it been possible to empirically examine the relationship between unpaid household production and recessions in the US as time use data from ATUS became available over a business cycle.

Focusing on the 2003-06 period, Burda and Hamermesh (2010) find a positive correlation between the metropolitan area unemployment rates and unpaid work hours in the US. When unemployment is measured at the individual level, however, it was correlated with a disproportionate increase in leisure time rather than home production. In a study of overall changes in time allocation, Aguiar, Hurst, and Karabarbounis (2011) find that during the recession years of 2009-2010, a pooled sample of women and men allocated a considerable share of the decline in their market work hours to nonmarket work (35 percent of the foregone market hours) and about 50 percent to leisure.

The main focus of these studies is changes in household production at the aggregate level with little attention to gender-differentiated effects of a worsening economy. Even when 
they examine changes for women and men separately, they do not examine how women fared relative to men. For example, Aguiar, Hurst, Karabarbounis (2011) compare the time use behavior of women and men during the high unemployment period to those of their counterparts in low unemployment periods. They also confirm that, when examined separately, women and men allocated a similar fraction of their foregone market hours to unpaid work and nonmarket activities. That said, they report that paid work experiences of women and men were quite different between 2008 and 2010 (men's paid work hours declined by 10.8 percent while women's paid work hours declined by only 0.3 percent). This disproportionate decline in men's paid hours combined with a proportional increase in unpaid work hours of women and men suggests a widening of the total work gap between women and men during the recession. This implication, in turn, renders questionable the claims of Burda, Hamermesh, and Weil (2012), who suggest that the total work burden of women and men has remained at parity in downturns as well as in non-recession times. However, the authors do not examine the gender difference in total workloads.

Aguiar, Hurst, and Karabarbounis (2011) also report that when their paid work hours declined, women and men moved into different types of unpaid work: Women did more core housework (cooking, cleaning, laundry) than men, while men increased their time in lawn and garden care, home maintenance and improvement (interior and exterior maintenance, repairs, cleaning, improvements) more than women. In non-work time, again, there were notable gender differences: women allocated more time to sleep while men watched more television. Men also allocated more of their time to education and own medical care than women. A quick assessment of the descriptive statistics in Aguiar, Hurst, and Karabarbounis suggests a narrowing the difference in women's and men's unpaid work hours, which may owe to increase in men's housework hours in activities other than core housework. Moreover, men's leisure time and, to a lesser extent, personal care hours relative to women may have increased. However, the authors do not examine these gender differences.

Other studies based on ATUS data specifically address gender asymmetries in the caregiving time of unemployed women and men during the recession. Hartmann, English, and Hayes (2010) show that in 2008, individual unemployment doubled women's caregiving time while it increased men's caregiving time only slightly. Unemployed men spent twice as much time on housework as employed men, but much less compared to unemployed women. Consistent with this evidence, Aguiar, Hurst, and Karabarbounis (2011) show that a larger 
proportion of women's foregone market work hours were allocated to childcare than were men's during the recession.

With the economic downturn, married-couple families in which only the wife engaged in paid work jumped from 6.9 percent of all married-couple families in 2008 and 8.4 percent in 2009 (BLS 2010a). This increase reflected a decline in the proportion of dual-income earners among married couples, while the proportion of married-couple families in which the husband was the only employed member remained unchanged. The percentage of married-couple families with own children under 18 with an unemployed husband and an employed wife also nearly doubled from 1.8 percent in 2008 to 3.4 percent in 2009 (Woodring 2010). Mattingly and Smith (2010) show that wives of husbands who ceased employment during the current recession were twice as likely to enter the labor force, particularly among those with older children or no children. These patterns are consistent with the findings of Juhn and Potter (2007), who report that women are 5 to 6 percent more likely to enter employment if their husbands exit employment, and that this "added worker" effect held in the 2001 recession.

Examining coupled parents' time allocation over the 2003-09 period, Morrill and Pabilonia (2012) find that mothers provided more childcare during the pre-recessionary period, while fathers provided more childcare as the economy worsened. While mothers' total time with children was invariant to state unemployment rates, at higher unemployment rates the time they spent on educational (enriching) childcare activities such as socializing and attending cultural events with children decreased, albeit not at conventional levels of statistical significance (Morrill and Pabilonia 2012). As the state unemployment rates reached above 8 percent, fathers spent more time in enriching childcare activities, which they attribute to the greater likelihood of nonstandard (including weekend) employment hours for mothers in a high unemployment context.

This evidence suggests that one way in which the recession might have affected time use of mothers and fathers is by increasing the effect of spousal factors on paid and unpaid uses of time. If so, this would be a reversal of the trend since 1980, whereby married women's, including mothers', labor supply decisions have became less responsive to their husbands' labor market behavior (Blau and Kahn 2007; Boushey 2008). Based on 2003-04 ATUS data, Connelly and Kimmel (2009) find that on week days, mothers and fathers are both unresponsive to unpaid uses of each other's time. On weekends, however, mothers' housework hours increased along with their spouses' housework hours. 
A similar complementarity might emerge in childcare during a downturn. In households with employed mothers, job losses, or reduction in paid work hours for fathers, fathers might be lead to provide more childcare via the increasing availability of fathers. Increased childcare by fathers was observed after the 1991 recession in the US, albeit such an increase was temporary; as employment picked up, fathers' childcare hours declined (Casper and O'Connell 1998; US Census Bureau 2010). With respect to housework, while in non-recessionary times mothers tend to do less housework so as to finance the increase in their paid work hours, in a recession, in addition, they may dip into their childcare hours. A likely response, that again signals complementarity between spousal activities, might be for fathers to increase their housework and childcare hours. Recession might have also increased the need for more adult care and reduced shopping hours as mothers and fathers cut down on consumption. However, how these activities respond during a recession is unknown a priori.

Overall, based on the macroeconomic and microeconomic literatures, we expect that the widespread job losses for men and employment increases for women occasioned by the US recession were associated with decline in mothers' unpaid work hours and increase in fathers' unpaid work hours. Thus, the convergence in paid work hours of mothers and fathers during the recession would be coupled with convergence in unpaid work hours. However, we expect a slower convergence in unpaid work compared to paid work. One reason is the rigidity in gender norms. Just as childcare hours of employed mothers are not responsive to their entry into the labor force or increased hours at paid work, housework hours of fathers may not be responsive to the decline in their labor market hours or change in employment status. Secondly, prior to the recession, the trends in paid and unpaid work were nearly at a standstill, hitting perhaps a limit within the current institutional context, especially in unpaid work. Such combination of shifts in paid and unpaid work would have repercussions for leisure or personal care hours. Examining the ensuing changes in total work and non-work hours will help identify gender differences in the well-being impacts of the recession.

Given the gender-asymmetric recovery in the job market after the official end of the recession in June 2009, it is possible that the changes in unpaid work hours either were reversed or continued at a slower rate. Job gains for fathers while mothers' employment was flat, especially after January 2010 (Kochhar 2011; IWPR 2011b), suggest a return to the paid work patterns of the prerecession years. Should the ATUS data reflect these changes, in the jobless recovery period we expect slowdown or reversal of changes in the area of unpaid work. 


\section{DATA AND METHOD}

Our sample comprises of 25,430 ATUS time diary respondents between the ages of 18 and 65 who resided in the same household with their spouse and at least one child. We exclude women and men who were in the armed forces, students, self-employed or employed without pay. The sample includes 13,439 mothers and 11,991 fathers. Appendix Table 1 reports the individual and household characteristics of these mothers and fathers. We weighted all observations using harmonized individual weights provided by the ATUS, which renders the sample of mothers and fathers representative of the US population of mothers and fathers.

Following the recent studies that examine ATUS data, we aggregate detailed activities into four alternative uses of time: paid (market) work, unpaid (nonmarket) work, leisure, and personal care activities (Connelly and Kimmel 2009; Kimmel and Connelly 2007). ${ }^{8}$ Prior to the recession, during January 2003 - November 2007, these four uses of time accounted for 92.4 percent of mothers' and 92.7 percent of fathers' weekly activities, with the rest of the time spent on government and civic obligations, volunteer activities, telephone conversations, and/or education.

Total work time is the sum of hours spent in paid and unpaid work. Along with Aguiar, Hurst, and Karabarbounis (2011), we define paid (market) work as time spent in activities for pay, and include in this category all time spent working in the market sector on main jobs, second jobs, and overtime, including any time spent commuting to/from work and time spent on work-related activities.

We distinguish among alternative uses of non-market time of unpaid work, leisure, and personal care based on the third-party principle. Unpaid work comprises of activities that one could pay a third party to perform, but for which one is not paid. Housework encompasses all types of housework, such as interior and exterior cleaning, laundry, and sewing. We keep shopping as a distinct category, since some types of shopping, such as purchases of clothing, are enjoyable activities that are akin to leisure, while others, such as grocery shopping, may be more like housework. Moreover, especially during recessions when the opportunity cost of time declines for the unemployed, shopping more hours might be a way for households to sustain their pre-recession consumption levels (Aguiar and Hurst 2007). They might thereby reduce the expenditures (for example, by finding lower-priced goods). While the same strategy might apply 
to other items, there is also the option of foregoing or delaying purchases of these items, with declining household income. These considerations make the relationship between shopping hours and the recession unknown a priori.

We keep childcare and housework as separate categories of work since, unlike home production of goods and services, parental childcare has an investment component and is likely to be more enjoyable than housework (Connelly and Kimmel 2010; Guryan, Hurst, and Kearney 2008). Moreover, recent studies show that childcare time behaves neither like housework nor like leisure; it is done more on the weekdays while housework can be delayed or foregone completely when time constraints intensify (Kimmel and Connelly 2007).

Childcare comprises primary care activities of providing physical care for children; reading to, playing with, and looking after children; doing arts and crafts, playing sports; talking with and listening to children; organizing, planning, and attending children's events; and picking up or dropping off children. ${ }^{9}$ We examine childcare as a general category and also, following Morrill and Pabilonia (2012), we differentiate between routine childcare and enriching childcare activities. Routine care involves attending to the basic needs of children such as feeding and bathing them, while enriching childcare entails any time spent on educational activities such as reading to/with children, helping them with homework, or attending social events with children. ${ }^{10}$

We include adult care as a separate category of care that is likely to be affected by the recession. Adult care consists of providing physical and medical care for adults (those 18 and over), obtaining medical and care services for them, and the waiting associated with these activities. These adults are either household members or reside in another household. While still under discussion, adult caregiving is different than child care as it probably does not have an investment component. Recession may have created additional work caring for adults, as their health deteriorates, for example, because they delayed hospital care, doctor's visits, and prescription drug purchases when they lost income, jobs, and health insurance, or simply due to the presence of the unemployed spouse in the household.

Leisure comprises of activities that one cannot pay someone else to do. We include in this category television watching, listening to music, socializing with friends, and other recreational activities. Personal care comprises of sleeping, own medical care, and other activities related to satisfying needs. Like leisure, one cannot pay a third party to do these activities but, unlike leisure, doing at least some of these activities is necessary for survival. 
The time use patterns prior to 2007 suggest that women spend more time in these activities than men, while men spend more time on leisure activities than women (Aguiar and Hurst 2007).

We examine the effect of the recession using the National Bureau of Economic Research (NBER) dating of the 2003-10 business cycle: expansion (January 2003 - November 2007), crisis and recession (December 2007-June 2009), and recovery (July 2009 - December 2010). The concern with the NBER dating is that average weekly hours in paid work did not begin to fall dramatically until about six months into the NBER dated recession, and most job losses came between 2008 and 2009 (Kroll 2011, Morrill and Pabilonia 2012). Aguiar, Hurst, and Karabarbounis (2011) reason that the greatest drop in paid work hours and increase in the unemployment rate occurred between 2008 and 2009, and consider 2009 and 2010 as the recession years. However, this job loss approach to dating the recession does not accurately reflect the experience of mothers, whose paid work hours increased notably between 2007 and 2008 as they entered the labor force to supplement family income in response to the downturn (Şahin, Song, and Hobijn 2010). As a result, we use the NBER's dating of the cycle, and for sensitivity check, use the dating that emphasizes intensity of job losses. In the NBER method, we refer to the June 2009 - December 2010 period as the "extended unemployment" or “jobless recovery" period.

We distinguish the effect of the recession on time use by fitting a linear trend for each time use category for mothers, fathers, and the pooled sample over the January 2003 November 2007 period and extrapolating the values for December 2007 - December 2010 based on these trends. While the linear extrapolation is based on a rather brief period, the time use values during the pre-recession period are fairly consistent with the values reported in earlier studies that go back in time (Bianchi 2011; Connelly and Kimmel 2010; Guryan, Hurst, and Kearney 2008). We then isolate the "trend effect" from the "cycle effect" during the recession and the extended unemployment period based on ordinary least squares (OLS) estimation technique, where the dependent variable is the extrapolated weekly hours spent in each time use category. We attribute any difference between the observed and trend values to the recession (as the cycle effect), as distinct from the trend (the trend effect). We engage in a similar exercise to ascertain the cycle effect for the extended unemployment period (comparing the actual change during that period to the change indicated by the trend for that period) and for the combination of the recession and extended unemployment phases. This latter cycle effect can be interpreted 
as the overall effect of the recession as of December 2010.

\section{CHANGES IN EMPLOYMENT STATUS ACCORDING TO ATUS}

In order to provide the labor market context for the analysis of time use based on the ATUS data, we examine mothers' and fathers' employment status and paid work hours from 2003-10. Table 1 shows the changes according to two ways of dating the recession. According to the NBER method in the upper panel, in the pre-recession period, 44 percent of mothers were employed full-time, nearly 20 percent were in part-time jobs, about 4 percent were unemployed, and a third of them were out of the labor force. By comparison, prior to the recession, 89 percent of fathers were employed full-time, close to 3 percent were employed part-time, 3 percent were unemployed, and 5 percent were out of the labor force.

Between 2003 and 2010, mothers' and fathers' distribution across employment categories became more similar. According to the NBER dated cycle, during the recession, this convergence was driven primarily by the entry of mothers into the labor force as full-time workers and, to a lesser extent, by the opposite changes—an exit pattern—for fathers. The increase in mothers' labor force participation rate during the recession is consistent with both the long-term trend for women in the US and their entry into the labor force as added workers during previous recessions (Juhn and Potter 2007; Şahin, Song, and Hobijn 2010).

During the recession mothers' labor force participation rate increased by 3.6 percentage points, 2.6 percentage points of which took the form of an increase in the proportion of full-time employed women. Both mothers and, to a lesser extent, fathers also became unemployed during this period. However, unlike mothers, fathers moved into unemployment from full-time jobs. A smaller share of previously full-time employed fathers either found part-time employment or dropped out of the labor force.

After the official end of the recession in June 2009, referred to as the extended unemployment period in Table 1, there were reversals in mothers' employment status: The proportion of employed mothers declined slightly in full-time jobs and, to a lesser extent, in part-time work, as mothers became unemployed and moved out of the labor force. Despite the declines in mothers' labor force participation and employment, however, the convergence in mothers' and fathers' employment status continued, largely because the changes for fathers during the recession became more pronounced in the subsequent jobless recovery period as the 
proportion of unemployed fathers nearly doubled. This dramatic increase in unemployment was accompanied by a notable drop in the proportion of fathers who were employed fulltime. The increase in fathers' unemployment during this extended unemployment period reflects continued job losses until the end of 2009, as documented by the BLS data, well beyond the NBER dated end of the recession (BLS 2011).

As the lower panel in Table 1 shows, if intensity of job losses is used to date the recession and 2008 is considered part of the pre-recession period, the employment status changes for fathers are fairly consistent with the results of the NBER dated cycle. However, this approach contributes to a loss of information on mothers' employment status. Specifically, the jump in mothers' full-time employment participation during December 2007 and June 2009 and the continuous rise in mothers' unemployment rate are obscured. 
Table 1 Mothers' and fathers' distribution by employment status over the 2003-10 business cycle by NBER and job loss dating (percent)

\begin{tabular}{|c|c|c|c|c|c|c|c|c|}
\hline & & & ners & & & athers & & \\
\hline & $\begin{array}{l}\text { Full-time } \\
\text { Employed }\end{array}$ & $\begin{array}{l}\text { Part-time } \\
\text { Employed }\end{array}$ & Unemployed & $\begin{array}{l}\text { Out of } \\
\text { the labor } \\
\text { force }\end{array}$ & $\begin{array}{l}\text { Full-time } \\
\text { Employed }\end{array}$ & $\begin{array}{l}\text { Part-time } \\
\text { Employed }\end{array}$ & Unemployed & $\begin{array}{l}\text { Out of } \\
\text { the labor } \\
\text { force }\end{array}$ \\
\hline & \multicolumn{8}{|c|}{ NBER dating } \\
\hline \multirow{4}{*}{$\begin{array}{l}\text { Prerecession } \\
(2003-N o v e m b e r ~ 2007) \\
\text { Recession } \\
\text { (December 2007-June 2009) } \\
\text { Extended unemployment } \\
\text { (July 2009-2010) } \\
\end{array}$} & 44.0 & 18.9 & 3.9 & 33.2 & 89.2 & 2.6 & 3.0 & 5.1 \\
\hline & 46.6 & 18.9 & 4.9 & 29.6 & 88.4 & 2.8 & 3.6 & 5.2 \\
\hline & 45.5 & 18.1 & 6.0 & 30.4 & 83.2 & 4.2 & 6.9 & 5.7 \\
\hline & \multicolumn{8}{|c|}{ Job loss dating } \\
\hline $\begin{array}{l}\text { Prerecession } \\
\text { (2003-2008) } \\
\text { Recession }\end{array}$ & 44.7 & 18.8 & 4.3 & 32.2 & 88.9 & 2.7 & 3.3 & 5.1 \\
\hline$(2009-2010)$ & 44.9 & 18.4 & 5.6 & 31.1 & 81.8 & 4.6 & 7.0 & 6.6 \\
\hline Number of observations & 6,069 & 2,504 & 601 & 4,265 & 10,545 & 343 & 448 & 655 \\
\hline
\end{tabular}

Notes: Authors' calculations from ATUS data files 2003-10. The sample consists of 13,439 mothers and 11,991 fathers. The numbers are weighted averages of weekend and weekday samples. All observations are weighted by ATUS sampling weights. 
As for weekly hours at paid work, Table 2 shows that the recession (NBER-dated) occasioned a convergence similar to that in employment status as mothers' paid work hours increased and fathers' hours declined. After June 2009, the decline in paid hours of fathers continued, particularly among those employed part-time. Paid work hours of mothers with fulltime jobs declined slightly, while the hours of part-time employed mothers remained unchanged. Again, the job loss dating of the recession in the lower panel yields similar results for fathers, but obscures the increase in hours of full-time employed mothers, which occurred between December 2007 and June 2009. In fact, the job loss dating indicates that full-time employed mothers' hours declined during the recession.

Overall, the labor market experiences of ATUS respondent mothers and fathers became more similar over the business cycle. During the recession, this convergence was driven primarily by increases in mothers' labor force participation rate rather than disproportionate job losses for fathers. After June 2009, entry of mothers into the labor force stopped as unemployment among mothers rose, approaching the unemployment rate of fathers.

Table 2 Weekly paid work hours of full-time and part-time employed mothers and fathers by business cycle, 2003-10

\begin{tabular}{|c|c|c|c|}
\hline \multicolumn{4}{|c|}{ NBER dating } \\
\hline & & Mothers & Fathers \\
\hline \multirow[t]{3}{*}{ Full-time } & Prerecession (2003-November 2007) & 36.7 & 42.8 \\
\hline & Recession (December 2007-June 2009) & 38.2 & 42.0 \\
\hline & Extended unemployment (July 2009-2010) & 37.1 & 41.6 \\
\hline \multirow[t]{3}{*}{ Part-time } & Prerecession (2003-November 2007) & 20.4 & 33.5 \\
\hline & Recession (December 2007-June 2009) & 21.3 & 32.1 \\
\hline & Extended unemployment (July 2009-2010) & 21.2 & 25.1 \\
\hline \multicolumn{4}{|c|}{ Job loss dating } \\
\hline & & Mothers & Fathers \\
\hline \multirow[t]{2}{*}{ Full-time } & Prerecession (2003-2008) & 37.2 & 42.4 \\
\hline & Recession (2009-2010) & 36.2 & 42.5 \\
\hline \multirow[t]{2}{*}{ Part-time } & Prerecession (2003-2008) & 20.5 & 32.9 \\
\hline & Recession (2009-2010) & 22.5 & 24.1 \\
\hline
\end{tabular}

Notes: Authors' calculations from ATUS data files 2003-10. The sample consists of 13,439 mothers and 11,991 fathers. The numbers are weighted averages of weekend and weekday samples. All observations are weighted by ATUS sampling weights. 


\section{CHANGES IN MOTHERS' AND FATHERS' TIME USE OVER THE BUSINESS CYCLE}

How have these employment status and paid work hours changes affected mothers' and fathers' unpaid work, total work, leisure, and personal care hours? Did the recession have a notable impact on the trends in time use under way prior to the downturn?

We examine the recession's impact by using the NBER-dating of the cycle, which, as we established in the previous section, presents a more accurate portrait of the labor market changes under way for both mothers and fathers compared to the job loss dating. Table 3 presents the results of the trend analysis for the difference in the average weekly hours of mothers and fathers (mothers minus fathers). ${ }^{11}$ We report time spent in each category of work (paid, unpaid, and total) and non-work (personal care and leisure) before the recession and the changes with the recession, the jobless recovery period, and the combined changes over both of these periods. Table 4 shows the changes in time use of mothers and fathers that underlie the disparities reported in Table 3. In each table, columns 2, 5, and 8 report the actual changes experienced by mothers and fathers. Columns 4, 7, and 10 reflect the cycle effects over and above the trend effects reported in columns 3,6, and 9. The cycle effect reported in column 10 gauges the combined effect of the recession and the extended unemployment, and is numerically equal to the sum of the two cycle effects in columns 4 and 7.

Table 3, column 1 shows that before the recession, on average, fathers worked 21 hours more per week for pay compared to mothers, while mothers performed 20.1 hours more unpaid work per week than fathers. The total (paid and unpaid) work burden of mothers and fathers was nearly the same during this period (fathers worked close to an hour more per week). Likewise, non-work hours of fathers and mothers (sum of personal care and leisure time) were fairly similar, even though mothers spent 3.5 hours more in personal care activities compared to fathers, while fathers had 3.2 hours more leisure. As column 2 shows, during the recession, mothers' and fathers' paid and unpaid work hours converged: relative to fathers, mothers' work hours increased by 3.4 hours per week in paid work and declined by 2.2 hours per week in unpaid work.

While the changes in time use reported in column 2 are the ones experienced by (reported by) mothers and fathers during the recession, they may not be attributable entirely to the recession. It may well be that the trends under way prior to the recession would have 
brought about these changes even if there had been no financial crisis in 2007 . In order to isolate the recession's impact from the underlying trends, we apply a linear extrapolation to the 2003-07 data to identify the trend values for December 2007-June 2009. This trend effect is reported in column 3, while column 4 shows the recession's (cycle's) impact, that is, the observed values during the recession (column 2) minus the extrapolated values (column 3). As column 3 shows, in the absence of the recession, there would have been a small widening of the paid work gap coupled with a smaller narrowing of the unpaid hours gap, hence a relative increase in the total work hours of fathers. The difference in personal care hours would have increased slightly in favor of mothers and the leisure gap would have remained unchanged.

Column 4 shows that the recession overwhelmed these trend effects: when the prerecession trends are accounted for (i.e., the extrapolated values are subtracted from the observed changes during the recession), the recession contributed to the convergence in both the paid and the unpaid work hours of mothers and fathers. The total workload gap widened to the disadvantage of mothers, reversing the trend effect, and personal care time of fathers relative to mothers increased.

We trace the underlying changes in time use gaps in Table 4. The convergence in paid work hours due to the recession (the cycle effect in Table 3, column 4) was driven by an increase (by 1.7 hours) in mothers' paid work hours combined with a decline (by 2.4 hours) in fathers' paid work hours, both statistically significant at conventional levels. The narrowing gap in unpaid work hours was driven solely by a 1.5 hour per week decline in mothers' unpaid work. Without any change in unpaid work hours of fathers, fewer hours at paid work translated into fewer hours of total work for them, which nearly fully accounted for the rise in total workload gap in Table 3. Overall, the recession years contributed to the dual convergence in the paid and unpaid work hours of mothers and fathers, with the convergence in unpaid work driven by changes in, primarily, mothers' behavior. 
Table 3 Trend analysis of the gender differences in time spent on work and non-work activitieslover the 2003-2010 business cycle, NBER dating

\begin{tabular}{|c|c|c|c|c|c|c|c|c|c|c|}
\hline & (1) & (2) & (3) & (4) & (5) & (6) & (7) & (8) & (9) & (10) \\
\hline & $\begin{array}{c}\text { Observedpre } \\
\text { recession } \\
\text { average }\end{array}$ & $\begin{array}{c}\text { Observed } \\
\text { change } \\
\text { during } \\
\text { recession }\end{array}$ & $\begin{array}{l}\text { Trend } \\
\text { effect }\end{array}$ & $\begin{array}{c}\text { Cycle effect: } \\
\text { Recession }\end{array}$ & $\begin{array}{c}\text { Observed } \\
\text { change during } \\
\text { extended } \\
\text { unemployment }\end{array}$ & $\begin{array}{c}\text { Trend effect } \\
\text { during } \\
\text { extended } \\
\text { unemployment }\end{array}$ & $\begin{array}{c}\text { Cycle effect: } \\
\text { Extended } \\
\text { unemployment }\end{array}$ & $\begin{array}{c}\text { Observed } \\
\text { change (Dec. } \\
2007- \\
\text { Dec.2010) }\end{array}$ & $\begin{array}{c}\text { Trend effect } \\
\text { (Dec. 2007 - } \\
\text { Dec. 2010) }\end{array}$ & $\begin{array}{l}\text { Cycle effect } \\
\text { (Dec. 2007 - } \\
\text { Dec. 2010) }\end{array}$ \\
\hline \multicolumn{11}{|c|}{ Gap (Mothers- Fathers) } \\
\hline $\begin{array}{l}\text { Paid } \\
\text { work }\end{array}$ & $\begin{array}{l}-20.94 * * * \\
(0.62)\end{array}$ & $\begin{array}{r}3.39 * * * \\
(1.26)\end{array}$ & $\begin{array}{c}-0.69 * * * \\
(0.07)\end{array}$ & $\begin{array}{c}4.08 * * * \\
(1.26)\end{array}$ & $\begin{array}{l}1.62 \\
(1.58)\end{array}$ & $\begin{array}{r}-0.33 * * * \\
(0.03)\end{array}$ & $\begin{array}{l}1.94 \\
(1.58)\end{array}$ & $\begin{array}{r}5.01 * * * \\
(1.29)\end{array}$ & $\begin{array}{c}-1.01 * * * \\
(0.07)\end{array}$ & $\begin{array}{r}6.02 * * * \\
(1.29)\end{array}$ \\
\hline $\begin{array}{l}\text { Unpaid } \\
\text { work }\end{array}$ & $\begin{array}{l}20.11 * * * \\
(0.45)\end{array}$ & $\begin{array}{r}-2.18 * * \\
(0.92)\end{array}$ & $\begin{array}{c}-0.36^{* * * *} \\
(0.03)\end{array}$ & $\begin{array}{r}-1.82 * \\
(0.92)\end{array}$ & $\begin{array}{l}0.16 \\
(1.25)\end{array}$ & $\begin{array}{l}-0.17 * * * \\
(0.02)\end{array}$ & $\begin{array}{l}0.33 \\
(1.25)\end{array}$ & $\begin{array}{l}-2.02 * * \\
(0.94)\end{array}$ & $\begin{array}{c}-0.53 * * * \\
(0.04)\end{array}$ & $\begin{array}{l}-1.49 \\
(0.94)\end{array}$ \\
\hline Total & -0.83 & 1.22 & $-1.05^{* * *}$ & $2.26^{* *}$ & 1.78 & $-0.50 * * *$ & 2.27 & $2.99 * * *$ & $-1.54 * * *$ & $4.54 * * *$ \\
\hline work & $(0.54)$ & (1.09) & $(0.10)$ & (1.09) & (1.47) & $(0.05)$ & (1.47) & (1.11) & $(0.10)$ & (1.11) \\
\hline $\begin{array}{l}\text { Personal } \\
\text { care }\end{array}$ & $\begin{array}{l}3.45^{* * * *} \\
(0.29)\end{array}$ & $\begin{array}{r}-0.61 \\
(0.59)\end{array}$ & $\begin{array}{c}0.66 * * * \\
(0.06)\end{array}$ & $\begin{array}{c}-1.27 * * \\
(0.58)\end{array}$ & $\begin{array}{l}0.17 \\
(0.72)\end{array}$ & $\begin{array}{l}0.31 * * * \\
(0.03)\end{array}$ & $\begin{array}{l}-0.15 \\
(0.72)\end{array}$ & $\begin{array}{l}-0.45 \\
(0.60)\end{array}$ & $\begin{array}{c}0.97 * * * \\
(0.06)\end{array}$ & $\begin{array}{r}-1.42 * * \\
(0.60)\end{array}$ \\
\hline Leisure & $\begin{array}{l}-3.18 * * * \\
(0.41)\end{array}$ & $\begin{array}{r}-0.38 \\
(0.83)\end{array}$ & $\begin{array}{c}0.03 * * * \\
(0.00)\end{array}$ & $\begin{array}{l}-0.41 \\
(0.83)\end{array}$ & $\begin{array}{l}-1.92 * \\
(1.08)\end{array}$ & $\begin{array}{l}0.02 * * * \\
(0.00)\end{array}$ & $\begin{array}{l}-1.93 * \\
(1.08)\end{array}$ & $\begin{array}{r}-2.29 * * * \\
(0.85)\end{array}$ & $\begin{array}{c}0.05 * * * \\
(0.00)\end{array}$ & $\begin{array}{r}-2.34 * * * \\
(0.85)\end{array}$ \\
\hline
\end{tabular}

Notes: The sample consists of 13,439 mothers and 11,991 fathers. Standard errors are in parentheses. ***,**,* denote statistical significance at the 1,5 , and 10 percent levels.

${ }^{1}$ The sum of paid and unpaid work hours is total work time and the sum of time spent on personal care and leisure constitutes non-work time.

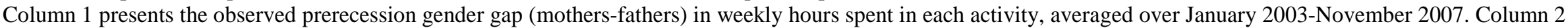
presents the change in the gap in each time use category between the recession period and the prerecession period. Column 3 presents the trend values based on

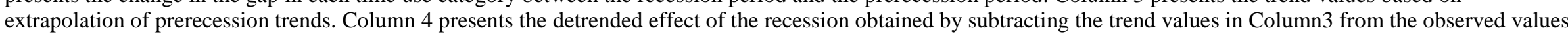

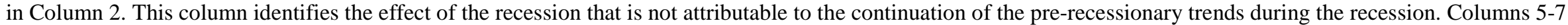

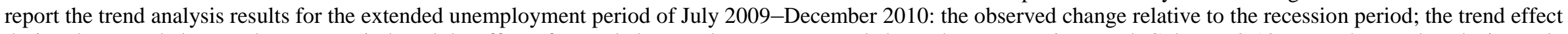

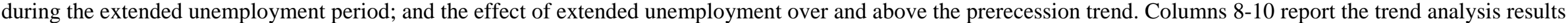

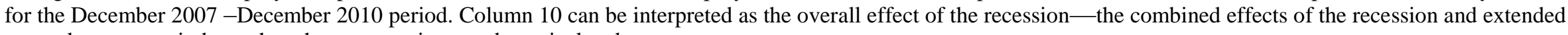
unemployment periods_-when the prerecession trends are isolated. 
Since job losses were more prominent after June 2009 as shown in Table 1, the recession's continued impact can be examined during this extended unemployment period relative to the recession period. Table 3 , column 7 , shows that during the jobless recovery period there was no statistically significant cycle effect on work hours gaps. As Table 4, column 7 shows, there was a continued decline in fathers' paid hours (by 3.2 hours per week), which reduced their weekly total workload by 2.2 hours, but these changes did not contribute to widening gaps in either type of work hours. The only statistically significant and notable cycle effect during the extended unemployment period was the widening of the leisure gap by almost 2 hours, owing to a larger increase in fathers' leisure time than the decline in mothers' leisure time, though neither change is precisely estimated. The changes in the work and non-work hours of mothers are not statistically significant, but there are signs of reversal of the patterns that prevailed during the recession. These reversals are consistent with the labor market changes during the jobless recovery period observed in Table 1; when mothers' entry into the labor force slowed down, their weekly paid work hours declined, and those who entered were more likely to be unemployed.

While high unemployment rates continued after December 2010, nonetheless, it is possible to take stock of the overall effect of the recession as of December 2010. Column 8 in Table 3 shows the changes actually experienced by mothers and fathers in the December 2007 December 2010 period. Relative to fathers, mothers took on 5 hours more paid work per week, did 2 hours less unpaid work, which led to an increase in their relative workload by 3 hours per week. Most of this increase in workload disparity came out of the decline in the relative leisure time of mothers (by 2.3 hours per week). Column 9 shows that, absent the recession, relative to fathers', mothers' paid work hours, unpaid work, and their total workload would have declined slightly. However, the recession overwhelmed and reversed the trend in paid work: the cycle effects reported in Column 10 of Table 3 show that compared to the pre-recession years, the paid work disparity between mothers and fathers narrowed by 6 hours per week to produce the 5 hour per week narrowing in disparity actually experienced by mothers and fathers. A similar reversal of trend occurred in total workload disparity, wherein the recession overall resulted in a 4.5 hours per week increase in total workload of mothers relative to fathers. Table 4 column 10 shows that these cycle effects were primarily driven by the decline in fathers' paid work hours and total workload. ${ }^{12}$ 
Table 4 Trend analysis of the time spent on paid, unpaid, total work, leisure and personal care over the 2003-10 business cycle, NBER dating

\begin{tabular}{|c|c|c|c|c|c|c|c|c|c|c|}
\hline & (1) & (2) & (3) & (4) & (5) & (6) & (7) & (8) & (9) & (10) \\
\hline & $\begin{array}{l}\text { Observed } \\
\text { pre- } \\
\text { recession } \\
\text { average }\end{array}$ & $\begin{array}{l}\text { Observed } \\
\text { change } \\
\text { during } \\
\text { recession }\end{array}$ & $\begin{array}{l}\text { Trend } \\
\text { effect }\end{array}$ & $\begin{array}{c}\text { Cycle } \\
\text { effect: } \\
\text { Recession }\end{array}$ & $\begin{array}{c}\text { Observed } \\
\text { change } \\
\text { during } \\
\text { extended } \\
\text { unemployment }\end{array}$ & $\begin{array}{l}\text { Trend effect } \\
\text { during } \\
\text { extended } \\
\text { unemployment }\end{array}$ & $\begin{array}{l}\text { Cycle effect: } \\
\text { Extended } \\
\text { unemployment }\end{array}$ & $\begin{array}{l}\text { Observed } \\
\text { change } \\
\text { (Dec. } \\
\text { 2007- } \\
\text { Dec.2010) }\end{array}$ & $\begin{array}{c}\text { Trend } \\
\text { effect } \\
\text { (Dec. } \\
2007 \text { - } \\
\text { Dec. } \\
2010 \text { ) }\end{array}$ & $\begin{array}{c}\text { Cycle } \\
\text { effect } \\
\text { (Dec. } \\
2007 \text { - } \\
\text { Dec. } \\
2010)\end{array}$ \\
\hline \multicolumn{11}{|c|}{ Mothers } \\
\hline Paid work & $\begin{array}{c}21.09 * * * \\
(0.44)\end{array}$ & $\begin{array}{c}2.04 * * \\
(0.89)\end{array}$ & $\begin{array}{c}0.33 * * * \\
(0.03)\end{array}$ & $\begin{array}{l}1.71 * \\
(0.89)\end{array}$ & $\begin{array}{l}-1.11 \\
(1.22)\end{array}$ & $\begin{array}{c}0.16 * * * \\
(0.02)\end{array}$ & $\begin{array}{l}-1.27 \\
(1.21)\end{array}$ & $\begin{array}{c}0.93 \\
(0.91)\end{array}$ & $\begin{array}{c}0.49 * * * \\
(0.03)\end{array}$ & $\begin{array}{c}0.44 \\
(0.91)\end{array}$ \\
\hline $\begin{array}{l}\text { Unpaid } \\
\text { work }\end{array}$ & $\begin{array}{r}42.49 * * * \\
(0.37)\end{array}$ & $\begin{array}{c}-2.34 * * * \\
(0.75)\end{array}$ & $\begin{array}{c}-0.82 * * * \\
(0.08)\end{array}$ & $\begin{array}{c}-1.51 * * \\
(0.75)\end{array}$ & $\begin{array}{c}1.00 \\
(1.12)\end{array}$ & $\begin{array}{c}-0.39 * * * \\
(0.04)\end{array}$ & $\begin{array}{c}1.39 \\
(1.12)\end{array}$ & $\begin{array}{l}-1.33^{*} \\
(0.77)\end{array}$ & $\begin{array}{c}-1.21 * * * \\
(0.08)\end{array}$ & $\begin{array}{l}-0.12 \\
(0.76)\end{array}$ \\
\hline Total work & $\begin{array}{c}63.58 * * * \\
(0.39)\end{array}$ & $\begin{array}{c}-0.3 \\
(0.79)\end{array}$ & $\begin{array}{c}-0.49 * * * \\
(0.05)\end{array}$ & $\begin{array}{c}0.19 \\
(0.79)\end{array}$ & $\begin{array}{l}-0.11 \\
(1.02)\end{array}$ & $\begin{array}{c}-0.23 * * * \\
(0.02)\end{array}$ & $\begin{array}{c}0.13 \\
(1.02)\end{array}$ & $\begin{array}{l}-0.40 \\
(0.81)\end{array}$ & $\begin{array}{c}-0.72 * * * \\
(0.05)\end{array}$ & $\begin{array}{c}0.32 \\
(0.80)\end{array}$ \\
\hline $\begin{array}{l}\text { Personal } \\
\text { care }\end{array}$ & $\begin{array}{c}64.94 * * * \\
(0.20)\end{array}$ & $\begin{array}{l}-0.42 \\
(0.40)\end{array}$ & $\begin{array}{c}0.22 * * * \\
(0.02)\end{array}$ & $\begin{array}{l}-0.64 \\
(0.40)\end{array}$ & $\begin{array}{c}0.31 \\
(0.46)\end{array}$ & $\begin{array}{c}0.10 * * * \\
(0.01)\end{array}$ & $\begin{array}{c}0.20 \\
(0.46)\end{array}$ & $\begin{array}{l}-0.11 \\
(0.40)\end{array}$ & $\begin{array}{c}0.32 * * * \\
(0.02)\end{array}$ & $\begin{array}{l}-0.44 \\
(0.40)\end{array}$ \\
\hline Leisure & $\begin{array}{c}26.53 * * * \\
(0.30)\end{array}$ & $\begin{array}{l}-0.05 \\
(0.60)\end{array}$ & $\begin{array}{c}-0.18 * * * \\
(0.02)\end{array}$ & $\begin{array}{c}0.13 \\
(0.60) \\
\end{array}$ & $\begin{array}{l}-0.75 \\
(0.89) \\
\end{array}$ & $\begin{array}{c}-0.09 * * * \\
(0.01)\end{array}$ & $\begin{array}{l}-0.66 \\
(0.89) \\
\end{array}$ & $\begin{array}{l}-0.80 \\
(0.61)\end{array}$ & $\begin{array}{c}-0.27 * * * \\
(0.02)\end{array}$ & $\begin{array}{l}-0.53 \\
(0.61) \\
\end{array}$ \\
\hline \multicolumn{11}{|c|}{ Fathers } \\
\hline Paid work & $\begin{array}{c}42.03 * * * \\
(0.56)\end{array}$ & $\begin{array}{l}-1.35 \\
(1.14)\end{array}$ & $\begin{array}{c}1.02 * * * \\
(0.10)\end{array}$ & $\begin{array}{c}-2.37 * * \\
(1.14)\end{array}$ & $\begin{array}{l}-2.72 * \\
(1.37)\end{array}$ & $\begin{array}{c}0.48 * * * \\
(0.05)\end{array}$ & $\begin{array}{c}-3.21 * * \\
(1.37)\end{array}$ & $\begin{array}{c}-4.08 * * * \\
(1.17)\end{array}$ & $\begin{array}{c}1.50 * * * \\
(0.10)\end{array}$ & $\begin{array}{c}-5.58 * * * \\
(1.16)\end{array}$ \\
\hline $\begin{array}{l}\text { Unpaid } \\
\text { work }\end{array}$ & $\begin{array}{c}22.38 * * * \\
(0.33)\end{array}$ & $\begin{array}{l}-0.16 \\
(0.67)\end{array}$ & $\begin{array}{c}-0.47 * * * \\
(0.04)\end{array}$ & $\begin{array}{c}0.31 \\
(0.66)\end{array}$ & $\begin{array}{c}0.84 \\
(0.91)\end{array}$ & $\begin{array}{c}-0.22 * * * \\
(0.02)\end{array}$ & $\begin{array}{c}1.06 \\
(0.91)\end{array}$ & $\begin{array}{c}0.68 \\
(0.68)\end{array}$ & $\begin{array}{c}-0.69 * * * \\
(0.05)\end{array}$ & $\begin{array}{l}1.37 * * \\
(0.68)\end{array}$ \\
\hline Total work & $\begin{array}{c}64.41^{* * * *} \\
(0.48)\end{array}$ & $\begin{array}{l}-1.51 \\
(0.96)\end{array}$ & $\begin{array}{c}0.56 * * * \\
(0.05)\end{array}$ & $\begin{array}{c}-2.07 * * \\
(0.96)\end{array}$ & $\begin{array}{l}-1.88^{*} \\
(1.06)\end{array}$ & $\begin{array}{c}0.26 * * * \\
(0.03)\end{array}$ & $\begin{array}{l}-2.15^{*} \\
(1.06)\end{array}$ & $\begin{array}{c}-3.40 * * * \\
(0.98)\end{array}$ & $\begin{array}{c}0.82 * * * \\
(0.05)\end{array}$ & $\begin{array}{c}-4.21 * * * \\
(0.98)\end{array}$ \\
\hline $\begin{array}{l}\text { Personal } \\
\text { care }\end{array}$ & $\begin{array}{c}61.49 * * * \\
(0.23)\end{array}$ & $\begin{array}{c}0.20 \\
(0.47)\end{array}$ & $\begin{array}{c}-0.44 * * * \\
(0.04)\end{array}$ & $\begin{array}{c}0.63 \\
(0.47)\end{array}$ & $\begin{array}{c}0.14 \\
(0.56)\end{array}$ & $\begin{array}{c}-0.21 * * * \\
(0.02)\end{array}$ & $\begin{array}{c}0.35 \\
(0.56)\end{array}$ & $\begin{array}{c}0.34 \\
(0.48)\end{array}$ & $\begin{array}{c}-0.64 * * * \\
(0.04)\end{array}$ & $\begin{array}{c}0.98 * * \\
(0.48)\end{array}$ \\
\hline Leisure & $\begin{array}{c}29.71 * * * \\
(0.35)\end{array}$ & $\begin{array}{c}0.33 \\
(0.72)\end{array}$ & $\begin{array}{c}-0.22 * * * \\
(0.02)\end{array}$ & $\begin{array}{c}0.54 \\
(0.72)\end{array}$ & $\begin{array}{c}1.17 \\
(0.83)\end{array}$ & $\begin{array}{c}-0.10 * * * \\
(0.01)\end{array}$ & $\begin{array}{c}1.27 \\
(0.83)\end{array}$ & $\begin{array}{c}1.50 * * \\
(0.73)\end{array}$ & $\begin{array}{c}-0.32 * * * \\
(0.02)\end{array}$ & $\begin{array}{l}1.81 * * \\
(0.73)\end{array}$ \\
\hline
\end{tabular}

Notes: Table 4 presents the changes in time use of mothers and fathers that underlie the changes in time use gaps presented in Table 3 . See Notes to Table 3 for

column definitions. 
In the case of unpaid work, the cycle reinforced the trend decline in unpaid work disparity (Table 3, columns 9 and 10), and was driven by a small but statistically significant increase in fathers' unpaid work (by 1.4 hours per week) (Table 4, column 10). Even though the cycle effect on unpaid work disparity is not statistically significant, it explains three-fourths of the actual convergence in unpaid work hours (Table 3, columns 10 vs. 8). Tables 3 and 4 also show that the cycle effects contributed to a narrowing of personal care time disparity as fathers increased their personal care hours, and a widening of the gap in leisure hours (by 2.3 hours per week), as the leisure time of fathers increased by 1.8 hours and mothers reduced theirs (albeit this drop is small and not statistically significant).

Tables 3 and 4 indicate that, despite considerable decrease in paid work hours of fathers, only when the combined effect of the recession and extended unemployment periods is considered is there a small statistically significant increase in fathers' unpaid hours. To examine the changes that may be at work in the components of unpaid work, we conduct the trend analysis for each unpaid work category, namely, housework, childcare, adult care, and shopping, and the gender differences (mothers-fathers) in each activity.

As Column 1 in Table 5 shows, in the years preceding the recession, on average, mothers spent more time on housework, childcare, and shopping than fathers. In the case of housework, the gap was almost 10 hours per week, followed by 7.7 hours in childcare. During the recession, there was a statistically significant decline in the childcare gap (by 1.1 hours per week), which was due to the fact that fathers spent about an hour more per week on childcare (column 2). Mothers reduced their weekly housework by 1.3 hours. Although not a statistically significant decline at conventional levels, the gap in housework was about an hour less during the recession. Both mothers and fathers spent less time shopping (with only the decline in mothers' shopping hours statistically significant), which left the shopping hours gap unchanged.

When the trend effect is isolated (Table 5, column 4), we find that the decline in the disparity in childcare hours observed during the recession was entirely due to the cycle effect. For childcare, the cycle effect amounts to 1.3 hours per week, reflecting a statistically significant rise in childcare by fathers and a smaller, weaker decline in childcare by mothers. The small statistically significant rise in disparity in adult care hours was entirely due to the increased care provided by mothers. ${ }^{13}$ The recession also narrowed the gender differences in housework and shopping hours, but these were not precisely estimated. Nonetheless, underlying the statistically significant decline in both the disparity in unpaid work and mothers' unpaid hours contributed by 
the recession (reported in Tables 3 and 4 ) is the fact that mothers reduced the time they spent on all unpaid tasks. Even as they picked up extra adult care during the recession, mothers ended up with less unpaid hours, attributable to the recession, because they put in fewer hours in all other unpaid chores.

During the extended unemployment period, the recession's effect on childcare hours of mothers and fathers disappeared (Table 5, column 7). Although these cycle effects are not statistically significant at conventional levels, during this phase fathers' childcare hours declined and mothers' childcare hours increased, suggesting a reversal for fathers and mothers. We find a larger, but statistically not significant, increase in fathers' housework hours suggesting that fathers shifted the additional time they devoted to childcare during the recession to housework in the jobless recovery period. However, the nearly 1 hour increase in fathers' housework hours did not result in a narrowing of the housework hours gap because mothers also increased their housework hours by the same amount.

When the cycle effect of the entire recessionary period is considered (Table 5, column 10), the only disparity that changed with any statistical precision was the increase in the difference in adult care hours, due to increase in the time mothers devoted to adult care. The gap in housework and childcare hours also narrowed, particularly as fathers took on more housework, but neither was strong enough to narrow the unpaid hours gap observed in Table 3, column 10 in a statistically significant manner. Nonetheless, it is notable that over half the increase in fathers' unpaid work (of 1.4 hours in Table 4, column 10) was due to the statistically significant increase in the time they spent on housework (Table 5, column 10). 
Table 5 Trend analysis of the changes in time spent on unpaid work activities over the 2003-10 business cycle, NBER dating

\begin{tabular}{|c|c|c|c|c|c|c|c|c|c|c|}
\hline & $(1)$ & (2) & (3) & (4) & (5) & $(6)$ & $(7)$ & $(8)$ & $(9)$ & $(10)$ \\
\hline & $\begin{array}{l}\text { Observed } \\
\text { pre- } \\
\text { recession } \\
\text { average }\end{array}$ & $\begin{array}{l}\text { Observed } \\
\text { change } \\
\text { during } \\
\text { recession }\end{array}$ & $\begin{array}{l}\text { Trend } \\
\text { effect }\end{array}$ & $\begin{array}{c}\text { Cycle } \\
\text { effect: } \\
\text { Recession }\end{array}$ & $\begin{array}{c}\text { Observed } \\
\text { change during } \\
\text { extended } \\
\text { unemployment }\end{array}$ & $\begin{array}{l}\text { Trend effect } \\
\text { during } \\
\text { extended } \\
\text { unemployment }\end{array}$ & $\begin{array}{l}\text { Cycle effect: } \\
\text { Extended } \\
\text { unemployment }\end{array}$ & $\begin{array}{l}\text { Observed } \\
\text { change } \\
\text { (Dec. } \\
2007- \\
\text { Dec.2010) }\end{array}$ & $\begin{array}{c}\text { Trend } \\
\text { effect } \\
\text { (Dec. } \\
2007 \text { - } \\
\text { Dec. } \\
2010 \text { ) }\end{array}$ & $\begin{array}{c}\text { Cycle } \\
\text { effect } \\
\text { (Dec. } \\
2007- \\
\text { Dec. } \\
2010)\end{array}$ \\
\hline \multicolumn{11}{|c|}{ Gap (Mothers- Fathers) } \\
\hline Housework & $\begin{array}{c}9.91 * * * \\
(0.28)\end{array}$ & $\begin{array}{l}-0.95 \\
(0.57)\end{array}$ & $\begin{array}{c}-0.31 * * * \\
(0.03)\end{array}$ & $\begin{array}{l}-0.63 \\
(0.57)\end{array}$ & $\begin{array}{l}-0.22 \\
(0.73)\end{array}$ & $\begin{array}{c}-0.15 * * * \\
(0.01)\end{array}$ & $\begin{array}{l}-0.07 \\
(0.73)\end{array}$ & $\begin{array}{c}-1.16 * * \\
(0.58)\end{array}$ & $\begin{array}{c}-0.46 * * * \\
(0.03)\end{array}$ & $\begin{array}{l}-0.70 \\
(0.58)\end{array}$ \\
\hline Childcare & $\begin{array}{c}7.74 * * * \\
(0.27)\end{array}$ & $\begin{array}{c}-1.14 * * \\
(0.55)\end{array}$ & $\begin{array}{c}0.14 * * * \\
(0.01)\end{array}$ & $\begin{array}{c}-1.28 * * \\
(0.55)\end{array}$ & $\begin{array}{c}0.67 \\
(0.74)\end{array}$ & $\begin{array}{c}0.07 * * * \\
(0.01)\end{array}$ & $\begin{array}{c}0.60 \\
(0.74)\end{array}$ & $\begin{array}{l}-0.47 \\
(0.56)\end{array}$ & $\begin{array}{c}0.21 * * * \\
(0.01)\end{array}$ & $\begin{array}{l}-0.68 \\
(0.56)\end{array}$ \\
\hline Adult care & $\begin{array}{l}-0.09 \\
(0.10)\end{array}$ & $\begin{array}{c}0.04 \\
(0.20)\end{array}$ & $\begin{array}{c}-0.39 * * * \\
(0.04)\end{array}$ & $\begin{array}{c}0.42 * * \\
(0.20)\end{array}$ & $\begin{array}{l}-0.14 \\
(0.23)\end{array}$ & $\begin{array}{c}-0.18 * * * \\
(0.02)\end{array}$ & $\begin{array}{c}0.04 \\
(0.23)\end{array}$ & $\begin{array}{l}-0.10 \\
(0.20)\end{array}$ & $\begin{array}{c}-0.57 * * * \\
(0.04)\end{array}$ & $\begin{array}{c}0.47 * * \\
(0.20)\end{array}$ \\
\hline Shopping & $\begin{array}{c}2.50 * * * \\
(0.17) \\
\end{array}$ & $\begin{array}{l}-0.34 \\
(0.35) \\
\end{array}$ & $\begin{array}{c}0.22 * * * \\
(0.02)\end{array}$ & $\begin{array}{l}-0.56 \\
(0.35) \\
\end{array}$ & $\begin{array}{c}0.14 \\
(0.38) \\
\end{array}$ & $\begin{array}{c}0.10 * * * \\
(0.01)\end{array}$ & $\begin{array}{c}0.04 \\
(0.38) \\
\end{array}$ & $\begin{array}{l}-0.20 \\
(0.36) \\
\end{array}$ & $\begin{array}{c}0.32 * * * \\
(0.02)\end{array}$ & $\begin{array}{l}-0.52 \\
(0.35) \\
\end{array}$ \\
\hline \multicolumn{11}{|c|}{ Mothers } \\
\hline Housework & $\begin{array}{c}19.93 * * * \\
(0.23)\end{array}$ & $\begin{array}{c}-1.25 * * * \\
(0.47)\end{array}$ & $\begin{array}{c}-0.52 * * * \\
(0.05)\end{array}$ & $\begin{array}{l}-0.73 \\
(0.46)\end{array}$ & $\begin{array}{c}0.56 \\
(0.60)\end{array}$ & $\begin{array}{c}-0.25 * * * \\
(0.02)\end{array}$ & $\begin{array}{c}0.81 \\
(0.59)\end{array}$ & $\begin{array}{l}-0.69 \\
(0.48)\end{array}$ & $\begin{array}{c}-0.77 * * * \\
(0.05)\end{array}$ & $\begin{array}{c}0.08 \\
(0.47)\end{array}$ \\
\hline Childcare & $\begin{array}{c}14.44 * * * \\
(0.23)\end{array}$ & $\begin{array}{c}-0.20 \\
(0.47)\end{array}$ & $\begin{array}{c}0.37 * * * \\
(0.04)\end{array}$ & $\begin{array}{l}-0.57 \\
(0.47)\end{array}$ & $\begin{array}{c}0.29 \\
(0.62)\end{array}$ & $\begin{array}{c}0.17 * * * \\
(0.02)\end{array}$ & $\begin{array}{c}0.12 \\
(0.62)\end{array}$ & $\begin{array}{c}0.09 \\
(0.48)\end{array}$ & $\begin{array}{c}0.54 * * * \\
(0.04)\end{array}$ & $\begin{array}{l}-0.45 \\
(0.48)\end{array}$ \\
\hline Adult care & $\begin{array}{c}1.03 * * * \\
(0.06)\end{array}$ & $\begin{array}{l}-0.13 \\
(0.12)\end{array}$ & $\begin{array}{c}-0.51 * * * \\
(0.05)\end{array}$ & $\begin{array}{c}0.37 * * * \\
(0.11)\end{array}$ & $\begin{array}{c}0.07 \\
(0.13)\end{array}$ & $\begin{array}{c}-0.24 * * * \\
(0.02)\end{array}$ & $\begin{array}{c}0.31 * * \\
(0.13)\end{array}$ & $\begin{array}{l}-0.07 \\
(0.12)\end{array}$ & $\begin{array}{c}-0.74 * * * \\
(0.05)\end{array}$ & $\begin{array}{c}0.68 * * * \\
(0.11)\end{array}$ \\
\hline Shopping & $\begin{array}{c}7.16^{* * * *} \\
(0.15) \\
\end{array}$ & $\begin{array}{c}-0.76^{* * *} \\
(0.31) \\
\end{array}$ & $\begin{array}{c}-0.16^{* * *} * \\
(0.02)\end{array}$ & $\begin{array}{l}-0.60 * \\
(0.31) \\
\end{array}$ & $\begin{array}{c}0.06 \\
(0.36) \\
\end{array}$ & $\begin{array}{c}-0.08 * * * \\
(0.01) \\
\end{array}$ & $\begin{array}{c}0.13 \\
(0.36) \\
\end{array}$ & $\begin{array}{c}-0.71 * * \\
(0.32) \\
\end{array}$ & $\begin{array}{c}-0.24 * * * \\
(0.02)\end{array}$ & $\begin{array}{l}-0.47 \\
(0.32) \\
\end{array}$ \\
\hline \multicolumn{11}{|c|}{ Fathers } \\
\hline Housework & $\begin{array}{c}10.02 * * * \\
(0.22)\end{array}$ & $\begin{array}{l}-0.31 \\
(0.44)\end{array}$ & $\begin{array}{c}-0.21 * * * \\
(0.02)\end{array}$ & $\begin{array}{l}-0.10 \\
(0.44)\end{array}$ & $\begin{array}{c}0.78 \\
(0.62)\end{array}$ & $\begin{array}{c}-0.10 * * * \\
(0.01)\end{array}$ & $\begin{array}{c}0.88 \\
(0.62)\end{array}$ & $\begin{array}{c}0.47 \\
(0.45)\end{array}$ & $\begin{array}{c}-0.31 * * * \\
(0.02)\end{array}$ & $\begin{array}{l}0.78 * \\
(0.45)\end{array}$ \\
\hline Childcare & $\begin{array}{c}6.70 * * * \\
(0.19)\end{array}$ & $\begin{array}{c}0.94 * * \\
(0.38)\end{array}$ & $\begin{array}{c}0.22 * * * \\
(0.02)\end{array}$ & $\begin{array}{l}0.71 * \\
(0.38)\end{array}$ & $\begin{array}{l}-0.38 \\
(0.57)\end{array}$ & $\begin{array}{c}0.11 * * * \\
(0.01)\end{array}$ & $\begin{array}{l}-0.49 \\
(0.57)\end{array}$ & $\begin{array}{c}0.56 \\
(0.39)\end{array}$ & $\begin{array}{c}0.33 * * * \\
(0.02)\end{array}$ & $\begin{array}{c}0.23 \\
(0.39)\end{array}$ \\
\hline Adult care & $\begin{array}{c}1.12 * * * \\
(0.08)\end{array}$ & $\begin{array}{l}-0.17 \\
(0.16)\end{array}$ & $\begin{array}{c}-0.12 * * * \\
(0.01)\end{array}$ & $\begin{array}{l}-0.05 \\
(0.16)\end{array}$ & $\begin{array}{c}0.21 \\
(0.18)\end{array}$ & $\begin{array}{c}-0.06 * * * \\
(0.01)\end{array}$ & $\begin{array}{c}0.26 \\
(0.18)\end{array}$ & $\begin{array}{c}0.04 \\
(0.17)\end{array}$ & $\begin{array}{c}-0.18 * * * \\
(0.01)\end{array}$ & $\begin{array}{c}0.21 \\
(0.16)\end{array}$ \\
\hline Shopping & $\begin{array}{c}4.66 * * * \\
(0.13)\end{array}$ & $\begin{array}{c}-0.42 \\
(0.26) \\
\end{array}$ & $\begin{array}{c}-0.38 * * * \\
(0.04)\end{array}$ & $\begin{array}{l}-0.04 \\
(0.26) \\
\end{array}$ & $\begin{array}{l}-0.09 \\
(0.28) \\
\end{array}$ & $\begin{array}{c}-0.18 * * * \\
(0.02) \\
\end{array}$ & $\begin{array}{c}0.09 \\
(0.28) \\
\end{array}$ & $\begin{array}{l}-0.50 * \\
(0.26) \\
\end{array}$ & $\begin{array}{c}-0.56^{* * *} * \\
(0.04)\end{array}$ & $\begin{array}{c}0.05 \\
(0.26) \\
\end{array}$ \\
\hline
\end{tabular}

Notes: See Notes to Table 3 for column definitions and the text for definitions of time use categories. 
Appendix Tables 2 and 3 provide a more detailed examination of the compositional changes in two unpaid household tasks during the recession-childcare and housework. In the case of childcare, in the years leading up to the recession, mothers devoted most of their childcare hours to routine tasks, while fathers split their childcare hours evenly between routine and enriching tasks (Appendix Table 2). Mothers devoted more time than fathers to both activities. The recession contributed to an increase in fathers' and a decrease in mothers' enriching activities with children, which in turn reduced the enriching childcare gap. There was no change in routine care hours, indicating that during the recession, mothers protected their routine childcare hours, a pattern documented for childcare overall for non-recession periods (Bianchi, Robinson, and Milkie 2006). As suggested by Morrill and Pabilonia (2012), it is possible that mothers increased their participation in nonstandard work that allowed them to maintain routine childcare while fathers took on enriching childcare during their shift.

For the extended unemployment period, the cycle effect on childcare hours of neither mothers nor fathers is statistically significant, albeit there are indications of reversal of the recession patterns in enriching childcare. When the recession effect for the entire December 2007 - December 2010 period is considered, its only notable impact on childcare was a small decline in the time mothers spent on enriching activities that narrowed the gap between mothers and fathers in this area.

In the case of housework, prior to the recession mothers performed the bulk of the core housework activities (cooking, cleaning, laundry), while "other" housework activities (e.g., repairs, lawn care) were relatively equally shared (Appendix Table 3). The recession narrowed the gender disparity in housework, primarily because mothers spent less time on core housework. This effect was reversed during the extended unemployment period, as mothers increased their core housework hours, which ended up leaving the gender disparity in core housework gap unaffected by the prolonged recession.

\section{SENSITIVITY TESTS}

In order to examine the robustness of these results, we conducted four analyses. First, we examine whether the results are sensitive to the dating of the recession. Second, we examine the effect of changing the sample of mothers and fathers on the trend analysis results, looking at the effect of age of children and the effect of being employed full-time. Finally, we introduce 
demographic controls to ascertain the robustness of results to changes in demographic characteristics over the 2003-10 period.

\section{9-2010 As the Recession Years}

When the recession is dated according to the intensity of job losses and January 2009 December 2010 is defined as the recession period there is no narrowing of the gap in unpaid work hours during the recession as neither mothers nor fathers registered a notable change in the time they allocated to unpaid work (Appendix Tables 4 and 5). Other results are fairly consistent with the earlier ones, albeit they are of smaller magnitude: the recession contributed to the narrowing of the paid work hours of mothers and fathers, but in this case, the sole source was the decline in paid work hours of fathers. With no change in the unpaid hours gap, the recession reduced the total work hours of men and widened the total workload gap. Likewise, the recession widened the gap in leisure hours as fathers allocated some of their foregone paid work hours to leisure (and to a smaller extent to personal care), which is a result we observed in the extended unemployment period.

Among the components of unpaid work, the only activity where the gap between mothers and fathers narrowed was shopping because mothers did less of it during the recession (Appendix Table 5). There was also a small increase in the time mothers devoted to adult care, but this increase did not contribute to a difference in adult care hours.

This analysis shows that, regardless of how the recession is dated, it contributed to an increase in the total workload of mothers relative to fathers. Thus, the phenomenon of iso-work, which held for our ATUS sample for the pre-December 2007 period, was not sustained during the recession. Comparing the results of different ways of dating the recession, on the other hand, indicates that the narrowing of the unpaid work gap was a fleeting change, specific to 2008, and a small one. We observe it if we include 2008 as a recession year and we do not see it if we presume 2008 represents a non-recession year. The reason is that in the job loss, dating the trend effects capture a portion of the cycle effects, hence reduce the magnitude of the latter or wipe them out in the case of unpaid work gap.

\section{Mothers and Fathers of Young Children}

We conducted the trend analysis for subsamples of mothers and fathers with younger children (with at least one child under age 6) and older children (between the ages of 6 and 17). ${ }^{14}$ 
Controlling for the trend, during the recession, the paid work hours gap narrowed for both samples of mothers and fathers, similar to that for the pooled group. However, focusing on subsamples indicates that the narrowing in the pooled sample was mainly driven by the statistically significant and large rise in the paid work hours of mothers of older children. Similarly, mothers and fathers of older children were the main contributors to the convergence in unpaid hours of the pooled sample of mothers and fathers during the recession.

During the extended unemployment period, the cycle effect on convergence in paid work hours was stronger for mothers and fathers of younger children, albeit not statistically precise in either sample. Furthermore, in paid work hours, this group shaped the effect of the entire recessionary period, and hence, the convergence of paid hours in the pooled sample was driven by mothers and fathers of young children for whom the paid work gap declined by nearly 7 hours per week.

\section{Full-Time Employed Mothers and Fathers}

Focusing on full-time employed mothers and fathers shows that they distributed their time more evenly across paid and unpaid work activities (Appendix Table 6). Prior to the recession, fulltime employed fathers spent about 7 more hours per week working for pay compared to fulltime employed mothers and about 10 hours less on unpaid work activities. Compared to the full sample, however, the relative work burden of mothers was considerably greater: the total workload of full-time employed mothers was 3.5 hours more per week compared to full-time employed fathers, while in the full-sample, mothers' relative work hours were virtually identical to fathers' (differed only by 0.8 hours). Thus, unlike the full sample, before the recession, the iso-work phenomenon did not hold among full-time employed mothers and fathers.

The recession's impact on the paid and unpaid work hours of the full-time employed mothers and fathers is similar to the impacts in the full sample, but smaller in magnitude and statistically not significant. The same holds for the cycle effect of the combined recession and extended unemployment period. However, a notable cycle impact is the nearly 2-hour statistically significant reduction in fathers' total work burden between December 2007 and December 2010, which, combined with an hour's increase in mothers' total workload, widened the total workload gap by an additional 3 hours per week. In the absence of the recession, the total workload disparity would have narrowed by a statistically significant 1.4 hours per week, but the cycle effect overwhelmed and reversed this trend effect. As a result, the disparity in total 
workload experienced by full-time employed mothers and fathers only widened over the course of the recession, amounting to an overall increase of 1.5 hours per week (albeit this is not precisely estimated).

\section{Other Sample Characteristics}

While the trend analysis presented above controls for aggregate trends in the US economy in the pre-recession period, it does not include controls for demographic characteristics of the mothers and fathers participating in the ATUS, such as age, education, race, ethnicity of respondents, or their household characteristics, such as the number of children in the household. A concern is that changes in these characteristics, which have a bearing on time use, might bias our results. To examine this potential effect on our results, we use the underlying micro-data from ATUS to calculate the distribution of mothers and fathers in our sample across various groups in the three phases of the 2003-10 business cycle.

As Appendix Table 1 shows, over this period there were virtually no changes in the demographic characteristics of the respondents' in the ATUS samples we used. Nevertheless, we estimate the effect of the cycle on the difference in weekly paid, unpaid, and total work hours of mothers and fathers in a multivariate framework that controls for demographic characteristics. The dependent variable is the difference in mothers' and fathers' weekly hours of work, for which we use the monthly gender gap estimates for the cycle effect from our trend analysis. The independent variables are dummy variables for the recession and the extended unemployment period (with the pre-recession period as the reference period), and demographic controls that are distributions of a pooled sample of mothers and fathers across individual and household characteristics. ${ }^{15}$ This estimation allows us to control for both the continuation of prerecession trends and the demographic shifts across periods.

The results on the dummy variables for the recession and extended unemployment periods are similar to the cycle effects in columns 4 and 10 of Table 3, in magnitude (economic significance) and statistical significance (Appendix Table 7). ${ }^{16}$ Thus, our results on the effect of the cycle over and above the trends established in the pre-recession period are robust to the demographic characteristics of the sample. 


\section{CONCLUSION}

This study examined the impact of the post-2007 financial crisis US recession on time use patterns of mothers and fathers. The main question of interest was whether the narrowing gender gap in paid work during the recession was mirrored in unpaid work and the extent to which it was. Coming at a historical moment when there was little change in the gendered patterns of unpaid and paid work of mothers and fathers, the recession presented the possibility for renewed movement toward gender convergence in work hours of mothers and fathers. In particular, the intensity and distinct gender patterns of unemployment of the recession may have contributed to decline in the disproportionate unpaid work burden of mothers relative to fathers. And unlike the earlier recessions of 1991 and 2001, the prolonged high unemployment rates in the latest US recession offered more time for new gender patterns of time use to settle.

Based on trend analysis, we identified the effect of the recession and the prolonged jobless recovery on time use, over and above the pre-recession trends. Had the pre-recession trends continued, absent the recession, there would have been very little change in the relative hours of work and non-work time of mothers and fathers. Fathers' paid work hours relative to mothers' would have increased slightly, with a counterpart increase in their relative total workload.

Instead, we find that the recession contributed to a short-lived dual convergence in paid and unpaid work of mothers and fathers. The recession narrowed the paid work hours gap and this was accompanied by narrowing of the difference in unpaid work hours, but this latter effect was small and temporary, not lasting beyond June 2009. These results hold for different subgroups of mothers and fathers - those with younger children, older children, those employed in full-time jobs. Based on different dates for the recession, we also determined that the recession's effect on the unpaid work hours disparity was confined to 2008, a narrow window within the NBER dated recession.

The decline in disparity in unpaid work during the recession was driven by an increase in fathers' childcare hours and a decline in unpaid hours of mothers in the form of small declines in shopping, housework, and childcare. With the reversal of the patterns in childcare and stagnant gap in other unpaid tasks, the narrowing in unpaid work attributable to the recession did not continue in the extended unemployment period (the jobless recovery) after June 2009. The reversal is consistent with the findings of Berik and Kongar (2011) who traced the U- 
shaped pattern in unpaid work over the course of the business cycle to stalling progress in housework hours during the extended unemployment period.

The prolonged stagnation in the labor market allowed us to take stock of the overall effect of the recession as of December 2010 as well as tracing the changes between the recession and extended unemployment phases. Overall, the recessionary December 2007 December 2010 period contributed to considerable convergence in paid work hours, which in the absence of a counterpart change in unpaid work, ended up having spillover effects on total workload and leisure hours. Relative to fathers, on average, mothers ended up with 5 hours more paid work, 2 hours less unpaid work, 3 hours more total workload and 2.3 hours less leisure time. The recession (the cycle effect) was a strong contributor to these actual experiences of mothers and fathers, reversing trends in the case of paid work and total workload, and slightly reinforcing the trend in the case of unpaid work. The cycle effects show that with fewer paid work hours and a smaller increase in their unpaid work, fathers ended up with a lower total workload and an increase in time for both personal care and leisure. As a result, relative to fathers', mothers' total workload increased and their leisure time declined.

Before the recession, mothers' weekly total work hours (paid work, housework, shopping, care work) and their non-work hours (personal care and leisure) were about the same as those of fathers. Total hours began to diverge during the recession and, together with the jobless recovery period, the recession contributed to a larger gap (of 4.5 hours per week) in total workload, which brought about an actual increase in the workload disparity by 3 hours per week. Among fathers and mothers who were employed full-time, there was no parity in total workloads prior to the recession and the recession contributed to widening the disparity (by almost 3 hours per week). In doing so, the recession reversed the narrowing trend in total workloads of this group of mothers and fathers. Thus, this study does not find evidence for the end of the "second shift" for full-time employed mothers.

Overall, the trend analysis shows that the recession provided the context for acceleration of the convergence in mothers' and fathers' paid work that was stalled in the early 2000s. With regards to unpaid work, our results for the recession are consistent with evidence on trends in gender disparity prior to the recession, that gender division in unpaid work is more resistant to change compared to paid work. Specifically, fathers are slower to adapt to the homemaker and caregiver roles compared to the seeming flexibility with which mothers adapt to the breadwinner role. This sluggishness is likely due to the social devaluation of reproductive tasks and 
the challenges these tasks present to masculine identity. Even during hard times, with shifting time constraints of mothers and fathers in labor market work, the gender division in unpaid work remained fairly intact.

Nonetheless, a close up on the stagnant unpaid work hours gap shows slight changes toward more unpaid work by fathers over the course of the recessionary period. During the recession, fathers increased the time they spent caring for children, particularly in enriching activities. However, this equalizing impact on childcare hours occurred only when mothers' paid work hours increased in absolute terms and also compared to fathers. It did not last when the decline in fathers' paid work hours relative to mothers continued during the extended unemployment period. The cycle effect of the overall recessionary period (December 2007 December 2010) was a small increase in fathers' unpaid hours due to a slight rise in their housework, which seems to have come at the expense of childcare. Thus the recession brought first increase in childcare hours of fathers, which then gave way to increase in housework over the course of the prolonged recession. However, the cycle's effect on time use of mothers and fathers is an unfolding story. In view of the ongoing stagnation in the job market in 2011, with men's unemployment rate higher than that for women for much of 2011, it is possible that the ATUS data for 2011 will indicate further changes in unpaid hours. Fathers might increase their unpaid hours as they adapt to having more time available due to the stagnant job market and as they take on additional unpaid tasks. Further decline in men's unemployment, accompanied by persistent high unemployment for women, however, is likely to prevent such adaptations.

While mothers and fathers constitute a substantial group in the ATUS sample, and we examined changes for three subsamples of mothers and fathers, future research should also assess the recession's impact on other groups of women and men. For example, sample size permitting, examining single women and men could yield different findings from the present analysis, especially given the heavier job losses for single women compared to their married counterparts during the recession. Similarly, the patterns for married women and men who don't have children are likely to be different. With fewer constraints in balancing (paid) work and family, women without children are likely to have greater flexibility to enter the labor force as added workers. The changes in paid work hours of this group during the recession are likely to be similar to that experienced by mothers of older children. For each group, the recession's impact on total workload is a key concern. This study showed that the recession did not provide the context for more equitable sharing of workload for mothers and fathers. Trend analyses for additional 
groups of women and men would help generate a comprehensive portrait of the gendered wellbeing effects of the recession. 


\section{REFERENCES}

Aguiar, Mark, Erik Hurst and Loukas Karabarbounis. 2011. Time Use During Recessions. NBER Working Paper No. 17259.

Aguiar, Mark and Erik Hurst. 2007. "Measuring Trends in Leisure: The Allocation of Time over Five Decades," The Quarterly Journal of Economics122(3): 969- 1006.

Benhabib, Jess, Richard Rogerson, and Randall Wright. 1991. "Homework in Macroeconomics: Household Production and Aggregate Fluctuations." Journal of Political Economy 99(6): 1166-1187.

Berik, Günseli, and Ebru Kongar. 2011. "Time Use of Mothers and Fathers in Hard Times and Better Times: The US Business Cycle of 2003-10.” Working Paper No. 696. Annandale-on-Hudson, NY: Levy Economics Institute of Bard College.

Bianchi, Suzanne M. 2011. "Family Change and Time Allocation in American Families." The ANNALS of the American Academy of Political and Social Science 638(1): 21-44.

Bianchi, Suzanne M., John P. Robinson, and Melissa Milkie. 2006. Changing Rhythms of American Family Life. New York: Russell Sage.

Bianchi, Suzanne M., Melissa A. Milkie, Liana C. Sayer and John P. Robinson. 2000. 'Is Anyone Doing the Housework? Trends in the Gender Division of Household Labor." Social Forces 79:191-228.

Bianchi, Suzanne M., Vanessa R. Wight and Sara B. Raley. 2005. Maternal Employment and Family Caregiving: Rethinking Time with Children in the ATUS. ATUS Early Results Conference, Bethesda, MD.

Blair-Loy, Mary. 2003. Competing Devotions: Career and Family among Women Executives. Cambridge, MA: Harvard University Press.

Blau, Francine, D. and Lawrence M. Kahn. 2007. "Changes in the Labor Supply Behavior of Married Women: 1980-2000.” Journal of Labor Economics 25: 393- 438.

Boushey, Heather. 2008. "Opting Out? The Effect of Children on Women's Employment in the United States." Feminist Economics 14(1): 1-36.

Boushey, Heather and Ann O'Leary. (Eds). 2009. The Shriver Report: A Woman's Nation Changes Everything: A Study by Maria Shriver and the Center for American Progress. Washington D.C.: A Woman's Nation and Center for American Progress. Also available online at http://www.shriverreport.com/awn/index.php (accessed July 24, 2011). 
Burda, Michael, Daniel S. Hamermesh and Philippe Weil. 2012. "Total Work and Gender: Facts and Possible Explanations," SFB 649 Discussion Paper SFB649DP2012-007.

Burda, Michael and Daniel S. Hamermesh. 2010. "Unemployment, Market Work and Household Production.” Economic Letters 107: 131-133.

Casper, Lynne and Martin O'Connell. 1998. “Work, Income, the Economy, and Married Fathers as Child-care Providers. Demography 35: 243-50.

Coltrane, Scott. 2000. Research on Household Labor: Modeling and Measuring the Social Embeddedness of Routine Family Work. Journal of Marriage and the Family 62: $1208-1233$.

Connelly, Rachel and Jean Kimmel. 2010. Time Use of Mothers in the United States at the Turn of the 21st Century. Kalamazoo, Michigan, USA: W. E. Upjohn Institute for Employment Research.

_ 2009. "Spousal Influences on Parents' Non-Market Time Choices." Review of Economics of the Household 7(4): 361-94.

Greenwood, Jeremy, and Zvi Hercowitz. 1991. "The Allocation of Capital and Time over the Business Cycle." Journal of Political Economy, 99(6): 1188-1214.

Guryan, Jonathan, Erik Hurst, and Melissa Kearney. 2008. "Parental Education and Parental Time with Children." Journal of Economic Perspectives, 22(3): 23-46.

Hartmann, Heidi, Ashley English, and Jeffrey Hayes. 2010. Women and Men's Employment and Unemployment in the Great Recession. Institute for Women's Policy Research (IWPR) Publication C373. Available online at http://www.in.gov/icw/files/employment.pdf (accessed August 1, 2011).

Hays, Sharon. 1996. The Cultural Contradictions of Motherhood. New Haven: Yale. University Press.

Howie, Peter, John Wicks, John M. Fitzgerald, Douglas Dalenberg and Rachel Connelly. 2006. "Mothers' Time Spent in Spent in Care of Her Children and Market Work: a Simultaneous Model with Attitudes as Instruments," Applied Economic Letters 2006, 13(8): 503-06.

Institute for Women's Policy Research (IWPR). 2011a. Are Women Now Half the Labor Force? The Truth about Women and Equal Participation in the Labor Force. Working Paper C374. Washington D.C.: IWPR. Also available online at http://www.iwpr.org/publications/pubs/are-women-now-half-the-labor-force-thetruthabout-women-and-equal-participation-in-the-labor-force/at download/file (accessed 
July 24, 2011).

. 2011b. Job Gap between Women and Men Persists in August. IWPR \#Q008 http://www.iwpr.org/publications/recent-publications (accessed September 15, 2011)

Jacobs, Jerry A. and Kathleen Gerson. 2004. The Time Divide: Work, Family and Gender Inequality. Cambridge, MA: Harvard University Press.

Juhn, Chinhui and Simon Potter. 2007. "Is There Still an Added Worker Effect?" Federal Reserve Bank of New York Staff Reports, no. 310, December.

Kimmel, Jean and Rachel Connelly. 2007. "Mothers' Time Choices: Caregiving, Leisure, Home Production, and Paid Work." Journal of Human Resources 42(3): 643-61.

Kochhar, Rakesh. 2011.Two Years of Economic Recovery: Women Lose Jobs, Men Find Them Pew Social \& Demographic Trends Report. Washington D.C.: Pew Research Center. Also available online at http://pewsocialtrends.org/files/2011/07/Employment-byGender FINAL 7-6- 11.pdf (accessed July 30, 2011).

Konigsberg, Ruth Davis. 2011. "Chore Wars," Time Magazine (August), Time Inc. available online at http://www.time.com/time/magazine/article/0,9171,2084582,00.html (accessed March 18, 2012).

Mattingly, Marybeth and Kristin Smith. 2010. "Changes in Wives' Employment When Husbands Stop Working: A Recession-Prosperity Comparison.” Family Relations 59:343-357.

Morrill, Melinda S., and Sabrina W. Pabilonia. 2012. "What Effects Do Macroeconomic Conditions Have on Families' Time Together?" Working Paper. Available online at http://www.sole-jole.org/12202.pdf (accessed March 17, 2012)

Ramey, Valerie A., and Neville Francis. 2009. "A Century of Work and Leisure." American Economic Journal: Macroeconomics 1(2): 189-224.

Ramey, Valerie A. 2008. "Time Spent in Home Production in the 20th Century: New Estimates from Old Data," NBER Working Papers 13985, National Bureau of Economic Research, Inc.

Risman, Barbara J. 1998. Gender Vertigo: American Families in Transition. Yale University Press.

Rones, Philip L., Randy E. Ilg and Jennifer M. Gardner. 1997. "Trends in Hours of Work Since the Mid-1970s." Monthly Labor Review 120: 3-14.

Sandberg, John and Sandra Hofferth. 2001.“Changes in Children's Time with Parent, U. S. 
1981-1997." Demography 38: 423-36.

Sayer, Liana C. 2005. "Gender, Time and Inequality: Trends in Women's and Men's Paid Work, Unpaid Work and Free Time." Social Forces 84(1): 285-303.

Sayer, Liana C., Philip N. Cohen and Lynne M. Casper.2004.'Women, Men and Work.” The American People Census 2000 Series. New York: Russell Sage and Population Reference Bureau.

Şahin, Ayşegul, Joseph Song, and Bart Hobijn. 2010. "The Unemployment Gender Gap During the 2007 Recession." Current Issues in Economics and Finance, Federal Reserve Bank of New York 16, no.2.

US Census Bureau. 2006. Current Population Survey Design and Methodology. Technical Paper 66.

- 2010. Who is Minding the Kids? Childcare Arrangements: Spring 2005/Summer 2006. Household Economic Studies. P70-121 Current Population Reports. Washington, D.C.: US Department of Commerce, US Census Bureau.

— 2011. "One-Third of Fathers with Working Wives Regularly Care for Their Children." US Census Bureau Reports. News release (December 5) http://www.census.gov/newsroom/releases/archives/children/cb11-198.html

US Department of Labor, Bureau of Labor Statistics [BLS]. 2010a. Employment, Hours, and Earnings from the Current Employment Statistics Survey. http://www.bls.gov/news.release/pdf/empsit.pdf (accessed July 24, 2011).

- 2010b. American Time Use Survey 2010 Results. http://www.bls.gov/news.release/pdf/atus.pdf(accessed March 18, 2012).

- 2011. Women in the Labor Force: A Databook. Report 1034.http://www.bls.gov/cps/wlf-databook2011.htm (accessed March 18, 2012).

US General Accounting Office 2001. Women in Management: Analysis of Selected Data from the Current Population Survey. Washington, DC: US GAO.

Williams, Joan. 2000. Unbending Gender: Why Family and Work Conflict and What to Do About It. New York: Oxford University Press.

Woodring, Braedyn. 2010. "Employment Status of Married-Couple Families by Presence of Own Children Under 18 Years: 2008 and 2009." American Community Survey Briefs ACSBR/09-10.Also available online at http://www.census.gov/prod/2010pubs/acsbr09$\underline{10 . p d f}$. 


\section{NOTES}

1. According to seasonally adjusted Current Employment Statistics data, the share of women in payrolls peaked in October 2009 at 49.96 percent (BLS 2010a). The seasonally unadjusted data show that women's share in payrolls reached 50.02 percent in November 2009 and peaked in January 2010 at 50.29 percent.

2. Children in the household include the respondents' own children, grandchildren, and/or foster children.

3. Connelly and Kimmel (2009) developed three alternative strategies to match mothers and fathers with time diaries to predict couples in the ATUS sample that future research can utilize to examine the impact of the recession on within-household gender division of labor.

4. Between 1970 and 2007 women's labor force participation rate increased by 16 percentage points from 43.3 percent in 1970 to 59.3 percent in 2007, while men's labor force participation fell 6.4 percentage points (BLS 2011, 7). Over the same period, the gender difference in weekly paid work hours narrowed due to an increase in women's paid work hours from 34.1 hours to 36.1 hours, while men's paid work hours remained unchanged at 41.7 hours (BLS 2011, 73).

5. Between 1975 and 1999, labor force participation of married mothers (with children under 18 years) rose from 47.4 percent to 71.3 percent and that of mothers with young (under age 6) children rose from 39 percent to 64.4 percent (BLS 2011).

6. According to BLS (2011) data, women's labor force participation rate increased by 7.6 percentage points in the 1970s and 5.9 percentage points in the 1980s, rose by only 2.5 percentage points in the 1990s and fell by 0.6 percentage points in the 2000s, prior to the recession. Similarly, gender convergence in paid work hours nearly stopped, narrowing by 0.5 (a half) hours in the early 2000s as men's paid work hours fell (by 0.8 hours per week) slightly more than the rise in women's paid work hours (BLS 2011).

7. Accordingly, the total work hours difference between men and women who were both employed fulltime and who did not have children dropped to 8 minutes per day. Even having children under 18 years of age amounted to what is deemed a fairly small difference in total work of 20 minutes per day for women and men. When translated into weekly hours, however, these minutes add up.

8. We add the travel time related to each of the four activities.

9. We leave out consideration of secondary activities because ATUS provides data on secondary care activities for only children younger than 13 . Our focus on primary care activities enables obtaining results that are generalizable to the US population and sample sizes large enough for robust findings.

10. Some analyses further distinguish among educational activities and treat activities such as playing games with children or attending social events as recreational childcare that they then consider as leisure (Aguiar and Hurst 2007; Burda, Hamermesh and Weil 2012; 
Ramey and Francis 2009).

11. Weekly values are the weighted sum of weekend and weekday values as follows: We calculate the daily time use for each activity separately for weekdays and weekends. Then we multiply weekend values by two and weekday values by five and add up the two to obtain the weekly hours spent on each activity. We weight observations by ATUS sample weights.

12. It is possible that fathers allocated some of the decline in their work hours to educational activities as Aguiar, Hurst, and Karabarbounis (2011) documented for 2009-2010. Student fathers are excluded in our sample and we are not considering education as an activity in this study.

13. Differentiating further the types of adult care, we find that the recession increased the time spent caring for household and non-household adults equally. Presence of the unemployed spouse at home may have contributed to increased care for household adults by mothers. These results, excluded here for brevity, are available from the authors upon request.

14. The results are available from the authors upon request.

15. The omitted categories in the regressions are the shares of respondents between the ages of 25 to 35 , with a high school education, living in households with three children, where the youngest child is between the ages of 10 and 14 .

16. We fail to reject the hypothesis that the mean difference is greater than zero. 
Appendix Table 1 Characteristics of mothers and fathers in the sample, 2003-10

\begin{tabular}{|c|c|c|c|c|c|c|c|c|c|}
\hline & & \multicolumn{5}{|c|}{ Mothers } & \multicolumn{3}{|c|}{ Fathers } \\
\hline & & $\begin{array}{c}2003-10 \\
\text { Average } \\
(1)\end{array}$ & $\begin{array}{l}\text { Pre-recession } \\
\text { (2) }\end{array}$ & $\begin{array}{l}\text { Recession } \\
\text { (3) }\end{array}$ & $\begin{array}{l}\text { Extended } \\
\text { unemp't } \\
(4)\end{array}$ & $\begin{array}{c}2003-10 \\
\text { Average } \\
(1)\end{array}$ & $\begin{array}{l}\text { Pre-recession } \\
\text { (2) }\end{array}$ & $\begin{array}{l}\text { Recession } \\
\text { (3) }\end{array}$ & $\begin{array}{l}\text { Extended } \\
\text { unemp't }\end{array}$ \\
\hline & Usual weekly earnings ${ }^{1}$ & $\$ 682.6$ & $\$ 643.8$ & $\$ 732.6$ & $\$ 757.6$ & $\$ 1,054.8$ & $\$ 1,017.3$ & $\$ 1,104.2$ & $\$ 1,133.8$ \\
\hline \multicolumn{10}{|c|}{$\begin{array}{r}\text { Share of respondents by demographic and } \\
\text { household characteristcs }{ }^{2}(\%)\end{array}$} \\
\hline Race/ethnicity & Hispanic & 17 & 17 & 18 & 17 & 16 & 15 & 17 & 17 \\
\hline Age of the & Younger than age 3 & 30 & 30 & 30 & 31 & 30 & 30 & 29 & 30 \\
\hline \multirow[t]{4}{*}{ youngest child } & Ages 3-5 & 20 & 20 & 21 & 19 & 20 & 20 & 20 & 20 \\
\hline & Ages 6-9 & 21 & 21 & 22 & 21 & 21 & 21 & 21 & 21 \\
\hline & Ages 10-13 & 17 & 17 & 16 & 16 & 17 & 16 & 18 & 15 \\
\hline & Ages 14-17 & 12 & 12 & 12 & 13 & 13 & 13 & 12 & 13 \\
\hline \multirow[t]{3}{*}{ Age group } & Ages 18-24 & 30 & 30 & 29 & 29 & 22 & 23 & 21 & 22 \\
\hline & Ages 45-54 & 3 & 3 & 3 & 4 & 6 & 5 & 6 & 7 \\
\hline & Ages 55-65 & 10 & 10 & 9 & 9 & 10 & 10 & 9 & 9 \\
\hline \multirow[t]{4}{*}{ Education } & $<$ High school diploma & 10 & 11 & 10 & 9 & 10 & 11 & 10 & 9 \\
\hline & High school & 24 & 26 & 22 & 22 & 26 & 26 & 24 & 26 \\
\hline & Some college & 27 & 27 & 26 & 26 & 25 & 25 & 26 & 24 \\
\hline & BA or more & 39 & 37 & 42 & 43 & 39 & 38 & 41 & 41 \\
\hline \multirow[t]{5}{*}{ No. of children } & 1 & 36 & 36 & 35 & 36 & 37 & 37 & 36 & 37 \\
\hline & 2 & 42 & 41 & 43 & 42 & 42 & 42 & 43 & 41 \\
\hline & 3 & 16 & 17 & 16 & 15 & 16 & 16 & 15 & 16 \\
\hline & 4 & 4 & 4 & 4 & 5 & 4 & 4 & 5 & 4 \\
\hline & 5 or more & 1 & 2 & 1 & 1 & 1 & 1 & 2 & 1 \\
\hline $\begin{array}{r}\text { Number of } \\
\text { observations }\end{array}$ & & & 8,703 & 2,422 & 2,314 & & 7,762 & 2,170 & 2,059 \\
\hline
\end{tabular}

Notes: The sample consists of 13,439 mothers and 11,991 fathers. All observations are weighted by ATUS sampling weights.

${ }^{1}$ Weekly nominal earnings of employed mothers and fathers.

${ }^{2}$ The percentage of mothers, fathers with selected individual and household characteristics. 
Appendix Table 2 Trend analysis of the changes in time spent on routine and enriching child care and related travel over the $2003-2010$ period, NBER dating

\begin{tabular}{|c|c|c|c|c|c|c|c|c|c|c|}
\hline & (1) & (2) & (3) & (4) & (5) & (6) & (7) & (8) & (9) & (10) \\
\hline & $\begin{array}{l}\text { Observed } \\
\text { prerecession } \\
\text { average }\end{array}$ & $\begin{array}{l}\text { Observed } \\
\text { change during } \\
\text { recession }\end{array}$ & $\begin{array}{l}\text { Trend } \\
\text { effect }\end{array}$ & $\begin{array}{l}\text { Cycle effect: } \\
\text { Recession }\end{array}$ & $\begin{array}{c}\text { Observed change } \\
\text { during extended } \\
\text { unemployment }\end{array}$ & $\begin{array}{c}\text { Trend effect during } \\
\text { extended } \\
\text { unemployment }\end{array}$ & $\begin{array}{l}\text { Cycle effect: } \\
\text { Extended } \\
\text { unemployment }\end{array}$ & $\begin{array}{l}\text { Observed change } \\
\text { (Dec. 2007- } \\
\text { Dec.2010) }\end{array}$ & $\begin{array}{l}\text { Trend effect } \\
\text { (Dec. 2007 - } \\
\text { Dec. 2010) }\end{array}$ & $\begin{array}{l}\text { Cycle } \\
\text { effect } \\
\text { (Dec. } \\
2007 \text { - }\end{array}$ \\
\hline \multicolumn{11}{|c|}{$\begin{array}{l}\text { Gap } \\
\text { rs - Fathers) }\end{array}$} \\
\hline Routine & $\begin{array}{c}4.67 * * * \\
(0.19)\end{array}$ & $\begin{array}{c}-0.66^{*} \\
(0.39)\end{array}$ & $\begin{array}{l}-0.56 * * * \\
(0.05)\end{array}$ & $\begin{array}{r}-0.10 \\
(0.38)\end{array}$ & $\begin{array}{c}-0.10 \\
(0.66)\end{array}$ & $\begin{array}{c}-0.08 * * * \\
(0.01)\end{array}$ & $\begin{array}{l}-0.02 \\
(0.66)\end{array}$ & $\begin{array}{r}-0.58 \\
(0.39)\end{array}$ & $\begin{array}{c}-0.82 * * * \\
(0.05)\end{array}$ & $\begin{array}{c}0.25 \\
(0.39)\end{array}$ \\
\hline Enriching & $\begin{array}{c}2.16^{* * * *} \\
(0.15)\end{array}$ & $\begin{array}{r}-0.53 * \\
(0.29)\end{array}$ & $\begin{array}{c}0.63 * * * \\
(0.06)\end{array}$ & $\begin{array}{c}-1.15^{* * * *} \\
(0.29)\end{array}$ & $\begin{array}{c}0.68 \\
(0.41)\end{array}$ & $\begin{array}{c}0.30 * * * \\
(0.03)\end{array}$ & $\begin{array}{c}0.39 \\
(0.41)\end{array}$ & $\begin{array}{c}0.16 \\
(0.30)\end{array}$ & $\begin{array}{c}0.92 * * * \\
(0.06)\end{array}$ & $\begin{array}{c}-0.76^{* * *} \\
(0.29)\end{array}$ \\
\hline $\begin{array}{l}\text { Related } \\
\text { travel }\end{array}$ & $\begin{array}{c}3.78 * * * \\
(0.25)\end{array}$ & $\begin{array}{c}0.17 \\
(0.50)\end{array}$ & $\begin{array}{l}-0.18 * * * \\
(0.02)\end{array}$ & $\begin{array}{r}0.34 \\
(0.50) \\
\end{array}$ & $\begin{array}{l}-0.10 \\
(0.66)\end{array}$ & $\begin{array}{c}-0.08 * * * \\
(0.01)\end{array}$ & $\begin{array}{l}-0.02 \\
(0.66)\end{array}$ & $\begin{array}{l}0.06 \\
(0.51) \\
\end{array}$ & $\begin{array}{c}-0.26 * * * \\
(0.02)\end{array}$ & $\begin{array}{r}0.32 \\
(0.51) \\
\end{array}$ \\
\hline \multicolumn{11}{|c|}{ Mothers } \\
\hline Routine & $\begin{array}{c}7.34 * * * \\
(0.15)\end{array}$ & $\begin{array}{r}-0.13 \\
(0.30)\end{array}$ & $\begin{array}{l}-0.36 * * * \\
(0.03)\end{array}$ & $\begin{array}{c}0.23 \\
(0.30)\end{array}$ & $\begin{array}{l}-0.29 \\
(0.37)\end{array}$ & $\begin{array}{c}-0.17 * * * \\
(0.02)\end{array}$ & $\begin{array}{l}-0.12 \\
(0.37)\end{array}$ & $\begin{array}{l}-0.42 \\
(0.31)\end{array}$ & $\begin{array}{c}-0.53 * * * \\
(0.03)\end{array}$ & $\begin{array}{c}0.11 \\
(0.31)\end{array}$ \\
\hline Enriching & $\begin{array}{c}5.31 * * * \\
(0.12)\end{array}$ & $\begin{array}{r}-0.14 \\
(0.24)\end{array}$ & $\begin{array}{r}0.64 * * * \\
(0.06)\end{array}$ & $\begin{array}{c}-0.78 * * * \\
(0.23)\end{array}$ & $\begin{array}{c}0.66 * * \\
(0.30)\end{array}$ & $\begin{array}{c}0.30 * * * \\
(0.03)\end{array}$ & $\begin{array}{c}0.35 \\
(0.29)\end{array}$ & $\begin{array}{r}0.51 * * \\
(0.24)\end{array}$ & $\begin{array}{c}0.94 * * * \\
(0.06)\end{array}$ & $\begin{array}{c}-0.42 * \\
(0.24)\end{array}$ \\
\hline $\begin{array}{l}\text { Related } \\
\text { travel }\end{array}$ & $\begin{array}{c}1.83 * * * \\
(0.06)\end{array}$ & $\begin{array}{c}0.10 \\
(0.11) \\
\end{array}$ & $\begin{array}{r}0.02 * * * \\
(0.00)\end{array}$ & $\begin{array}{c}0.08 \\
(0.11) \\
\end{array}$ & $\begin{array}{l}-0.05 \\
(0.15) \\
\end{array}$ & $\begin{array}{c}0.01 * * * \\
(0.00)\end{array}$ & $\begin{array}{l}-0.06 \\
(0.15) \\
\end{array}$ & $\begin{array}{c}0.05 \\
(0.11) \\
\end{array}$ & $\begin{array}{c}0.03 * * * \\
(0.00)\end{array}$ & $\begin{array}{c}0.02 \\
(0.11) \\
\end{array}$ \\
\hline \multicolumn{11}{|c|}{ Fathers } \\
\hline Routine & $\begin{array}{c}2.67 * * * \\
(0.12)\end{array}$ & $\begin{array}{l}0.53 * * \\
(0.24)\end{array}$ & $\begin{array}{r}0.20 * * * \\
(0.02)\end{array}$ & $\begin{array}{c}0.33 \\
(0.24)\end{array}$ & $\begin{array}{c}-0.38 \\
(0.38)\end{array}$ & $\begin{array}{c}0.09 * * * \\
(0.01)\end{array}$ & $\begin{array}{c}-0.47 \\
(0.38)\end{array}$ & $\begin{array}{c}0.15 \\
(0.25)\end{array}$ & $\begin{array}{c}0.29 * * * \\
(0.02)\end{array}$ & $\begin{array}{c}-0.14 \\
(0.25)\end{array}$ \\
\hline Enriching & $\begin{array}{c}3.15 * * * \\
(0.11)\end{array}$ & $\begin{array}{l}0.38 * \\
(0.22)\end{array}$ & $\begin{array}{r}0.01 * * * \\
(0.00)\end{array}$ & $\begin{array}{c}0.37 * \\
(0.22)\end{array}$ & $\begin{array}{l}-0.03 \\
(0.35)\end{array}$ & $\begin{array}{c}0.01 * * * \\
(0.00)\end{array}$ & $\begin{array}{l}-0.03 \\
(0.35)\end{array}$ & $\begin{array}{c}0.36 \\
(0.23)\end{array}$ & $\begin{array}{c}0.01 * * * \\
(0.00)\end{array}$ & $\begin{array}{c}0.34 \\
(0.23)\end{array}$ \\
\hline $\begin{array}{l}\text { Related } \\
\text { travel }\end{array}$ & $\begin{array}{c}0.88 * * * \\
(0.04)\end{array}$ & $\begin{array}{c}0.06 \\
(0.08)\end{array}$ & $\begin{array}{r}0.06 * * * \\
(0.01)\end{array}$ & $\begin{array}{c}0.00 \\
(0.08)\end{array}$ & $\begin{array}{l}-0.02 \\
(0.09)\end{array}$ & $\begin{array}{c}0.03 * * * \\
(0.00)\end{array}$ & $\begin{array}{l}-0.05 \\
(0.09)\end{array}$ & $\begin{array}{c}0.03 \\
(0.08)\end{array}$ & $\begin{array}{c}0.09 * * * \\
(0.01)\end{array}$ & $\begin{array}{l}-0.06 \\
(0.08)\end{array}$ \\
\hline
\end{tabular}

Notes: See Notes to Table 3 for column definitions and the text for definitions of time use categories. 
Appendix Table 3 Trend analysis of the changes in time spent on core and other housework activities over the 2003 -2010 business cycle, NBER dating

\begin{tabular}{|c|c|c|c|c|c|c|c|c|c|c|}
\hline & (1) & (2) & (3) & (4) & (5) & (6) & (7) & (8) & (9) & $(10)$ \\
\hline & $\begin{array}{l}\text { Observed } \\
\text { pre-recession } \\
\text { average }\end{array}$ & $\begin{array}{l}\text { Observed } \\
\text { change during } \\
\text { recession }\end{array}$ & $\begin{array}{l}\text { Trend } \\
\text { effect }\end{array}$ & $\begin{array}{l}\text { Cycle } \\
\text { effect: } \\
\text { recession }\end{array}$ & $\begin{array}{c}\text { Observed change } \\
\text { during extended } \\
\text { unemployment }\end{array}$ & $\begin{array}{l}\text { Trend effect } \\
\text { during extended } \\
\text { unemployment }\end{array}$ & $\begin{array}{l}\text { Cycle effect: } \\
\text { extended } \\
\text { unemployment }\end{array}$ & $\begin{array}{l}\text { Observed } \\
\text { change (Dec. } \\
\text { 2007- } \\
\text { Dec.2010) }\end{array}$ & $\begin{array}{l}\text { Trend effect } \\
\text { (Dec. 2007 - } \\
\text { Dec. 2010) }\end{array}$ & $\begin{array}{r}\text { Cycle effect } \\
\text { (Dec. 2007- } \\
\text { Dec. 2010) }\end{array}$ \\
\hline \multicolumn{11}{|c|}{$\begin{array}{r}\text { Gap } \\
\text { (Mothers - F }\end{array}$} \\
\hline Core & $\begin{array}{l}8.45 * * * \\
(0.17)\end{array}$ & $\begin{array}{c}-1.26 * * * \\
(0.34)\end{array}$ & $\begin{array}{c}-0.66 * * * \\
(0.06)\end{array}$ & $\begin{array}{l}-0.60 * \\
(0.34)\end{array}$ & $\begin{array}{c}0.31 \\
(0.44)\end{array}$ & $\begin{array}{r}-0.31 * * * \\
(0.03)\end{array}$ & $\begin{array}{c}0.62 \\
(0.45)\end{array}$ & $\begin{array}{c}-0.95 * * * \\
(0.35)\end{array}$ & $\begin{array}{l}-0.97 * * * \\
(0.06)\end{array}$ & $\begin{array}{c}0.02 \\
(0.35)\end{array}$ \\
\hline Other & $\begin{array}{l}1.47 * * * \\
(0.22)\end{array}$ & $\begin{array}{c}0.31 \\
(0.44)\end{array}$ & $\begin{array}{c}0.35 * * * \\
(0.03)\end{array}$ & $\begin{array}{l}-0.04 \\
(0.44)\end{array}$ & $\begin{array}{l}-0.52 \\
(0.55)\end{array}$ & $\begin{array}{r}0.16 * * * \\
(0.02)\end{array}$ & $\begin{array}{l}-0.69 \\
(0.55)\end{array}$ & $\begin{array}{l}-0.21 \\
(0.45)\end{array}$ & $\begin{array}{l}0.51 * * * \\
(0.03)\end{array}$ & $\begin{array}{l}-0.72 \\
(0.45)\end{array}$ \\
\hline \multicolumn{11}{|c|}{ Mothers } \\
\hline Core & $\begin{array}{c}11.17 * * * \\
(0.14)\end{array}$ & $\begin{array}{c}-1.07 * * * \\
(0.29)\end{array}$ & $\begin{array}{c}-0.50 * * * \\
(0.05)\end{array}$ & $\begin{array}{l}-0.57 * \\
(0.29)\end{array}$ & $\begin{array}{c}0.63 * \\
(0.36)\end{array}$ & $\begin{array}{c}-0.24 * * * \\
(0.02)\end{array}$ & $\begin{array}{c}0.87 * * \\
(0.36)\end{array}$ & $\begin{array}{l}-0.44 \\
(0.29)\end{array}$ & $\begin{array}{l}-0.74 * * * \\
(0.05)\end{array}$ & $\begin{array}{c}0.30 \\
(0.29)\end{array}$ \\
\hline Other & $\begin{array}{c}8.76 * * * \\
(0.17)\end{array}$ & $\begin{array}{l}-0.19 \\
(0.35) \\
\end{array}$ & $\begin{array}{c}-0.02 * * * \\
(0.00)\end{array}$ & $\begin{array}{r}-0.16 \\
(0.35) \\
\end{array}$ & $\begin{array}{l}-0.07 \\
(0.45) \\
\end{array}$ & $\begin{array}{c}-0.01 * * * \\
(0.00)\end{array}$ & $\begin{array}{l}-0.06 \\
(0.45) \\
\end{array}$ & $\begin{array}{l}-0.25 \\
(0.36) \\
\end{array}$ & $\begin{array}{c}-0.04 * * * \\
(0.00)\end{array}$ & $\begin{array}{l}-0.22 \\
(0.36) \\
\end{array}$ \\
\hline \multicolumn{11}{|c|}{ Fathers } \\
\hline Core & $\begin{array}{l}2.73 * * * \\
(0.09)\end{array}$ & $\begin{array}{c}0.19 \\
(0.19)\end{array}$ & $\begin{array}{c}0.16 * * * \\
(0.02)\end{array}$ & $\begin{array}{c}0.03 \\
(0.18)\end{array}$ & $\begin{array}{c}0.32 \\
(0.26)\end{array}$ & $\begin{array}{c}0.07 * * * \\
(0.01)\end{array}$ & $\begin{array}{r}0.25 \\
(0.26)\end{array}$ & $\begin{array}{l}0.51 * * * \\
(0.19)\end{array}$ & $\begin{array}{l}0.23 * * * \\
(0.02)\end{array}$ & $\begin{array}{r}0.28 \\
(0.19)\end{array}$ \\
\hline Other & $\begin{array}{r}7.29 * * * \\
(0.20)\end{array}$ & $\begin{array}{l}-0.50 \\
(0.40)\end{array}$ & $\begin{array}{l}-0.37 * * * \\
(0.04)\end{array}$ & $\begin{array}{l}-0.13 \\
(0.39)\end{array}$ & $\begin{array}{c}0.46 \\
(0.52)\end{array}$ & $\begin{array}{l}-0.18 * * * \\
(0.02)\end{array}$ & $\begin{array}{c}0.63 \\
(0.52)\end{array}$ & $\begin{array}{l}-0.04 \\
(0.40)\end{array}$ & $\begin{array}{l}-0.54 * * * \\
(0.04)\end{array}$ & $\begin{array}{l}0.50 \\
(0.40)\end{array}$ \\
\hline
\end{tabular}

Notes: See Notes to Table 3 for column definitions and the textfor definitions of time use categories 
Appendix Table 4 Trend analysis of the time spent on work and non-work activities over the 2003-10 business cycle, job loss dating ${ }^{1}$

\begin{tabular}{|c|c|c|c|c|}
\hline & & $(2)$ & (3) & (4) \\
\hline & $\begin{array}{c}\text { Observed } \\
\text { prerecession } \\
\text { average }\end{array}$ & $\begin{array}{l}\text { Observed change during } \\
\text { recession }\end{array}$ & Trend effect & $\begin{array}{l}\text { Cycle effect } \\
(2)-(3)\end{array}$ \\
\hline & \multicolumn{4}{|c|}{ Gap } \\
\hline Paid work & $\begin{array}{r}-20.53 * * * \\
(0.56)\end{array}$ & $\begin{array}{c}4.13 * * * \\
(1.15)\end{array}$ & $\begin{array}{c}1.43^{* * * *} \\
(0.14)\end{array}$ & $\begin{array}{r}2.50 * * \\
(1.11)\end{array}$ \\
\hline Unpaid work & $\begin{array}{r}19.77 * * * \\
(0.42)\end{array}$ & $\begin{array}{c}-1.88^{* *} \\
(0.83)\end{array}$ & $\begin{array}{c}-1.35 * * * \\
(0.12)\end{array}$ & $\begin{array}{r}-0.53 \\
(0.52)\end{array}$ \\
\hline Total work & $\begin{array}{l}-0.75 \\
(0.45)\end{array}$ & $\begin{array}{r}2.04 * * \\
(0.91)\end{array}$ & $\begin{array}{c}0.08^{* * * *} \\
(0.01)\end{array}$ & $\begin{array}{r}1.97 * * \\
(0.91)\end{array}$ \\
\hline Personal care & $\begin{array}{r}3.41 * * * \\
(0.26)\end{array}$ & $\begin{array}{r}-0.51 \\
(0.52)\end{array}$ & $\begin{array}{c}0.23 * * * \\
(0.02)\end{array}$ & $\begin{array}{r}-0.78 \\
(0.52)\end{array}$ \\
\hline \multirow[t]{2}{*}{ Leisure } & $\begin{array}{r}-3.18^{* * * *} \\
(0.36) \\
\end{array}$ & $\begin{array}{c}-1.49 * * \\
(0.72)\end{array}$ & $\begin{array}{c}-0.23 * * * \\
(0.02) \\
\end{array}$ & $\begin{array}{c}-1.72 * * \\
(0.72)\end{array}$ \\
\hline & \multicolumn{4}{|c|}{ Mothers } \\
\hline Paid work & $\begin{array}{r}21.40 * * * \\
(0.40)\end{array}$ & $\begin{array}{c}1.08 \\
(0.81)\end{array}$ & $\begin{array}{c}1.28 * * * \\
(0.12)\end{array}$ & $\begin{array}{r}-0.32 \\
(0.80)\end{array}$ \\
\hline Unpaid work & $\begin{array}{r}42.24 * * * \\
(0.34)\end{array}$ & $\begin{array}{c}-1.63 * * \\
(0.68)\end{array}$ & $\begin{array}{c}-1.59 * * * \\
(0.15)\end{array}$ & $\begin{array}{r}-0.00 \\
(0.67)\end{array}$ \\
\hline Total work & $\begin{array}{r}63.64 * * * \\
(0.35)\end{array}$ & $\begin{array}{l}-0.55 \\
(0.70)\end{array}$ & $\begin{array}{c}-0.31 * * * \\
(0.03)\end{array}$ & $\begin{array}{r}-0.33 \\
(0.64)\end{array}$ \\
\hline Personal care & $\begin{array}{r}64.86^{* * * *} \\
(0.18)\end{array}$ & $\begin{array}{l}-0.08 \\
(0.35)\end{array}$ & $\begin{array}{c}-0.14 * * * \\
(0.01)\end{array}$ & $\begin{array}{l}0.05 \\
(0.35)\end{array}$ \\
\hline \multirow[t]{2}{*}{ Leisure } & $\begin{array}{r}26.52 * * * \\
(0.27) \\
\end{array}$ & $\begin{array}{c}0.60 \\
(0.53)\end{array}$ & $\begin{array}{r}0.15^{* *} \\
(0.01) \\
\end{array}$ & $\begin{array}{r}-0.44 \\
(0.53)\end{array}$ \\
\hline & \multicolumn{4}{|c|}{ Fathers } \\
\hline Paid work & $\begin{array}{r}41.76^{* * * *} \\
(0.52)\end{array}$ & $\begin{array}{c}-3.05 * * * \\
(1.03)\end{array}$ & $\begin{array}{c}-0.20 * * * \\
(0.02)\end{array}$ & $\begin{array}{c}-2.82 * * * \\
(0.96)\end{array}$ \\
\hline Unpaid work & $\begin{array}{r}22.54 * * * \\
(0.30)\end{array}$ & $\begin{array}{l}0.24 \\
(0.59)\end{array}$ & $\begin{array}{c}-0.16^{* * * *} \\
(0.01)\end{array}$ & $\begin{array}{l}0.53 \\
(0.59)\end{array}$ \\
\hline Total work & $\begin{array}{r}64.30 * * * \\
(0.41)\end{array}$ & $\begin{array}{c}-2.81 * * * \\
(0.83)\end{array}$ & $\begin{array}{c}-0.36 * * * \\
(0.03)\end{array}$ & $\begin{array}{c}-2.29 * * * \\
(0.76)\end{array}$ \\
\hline Personal care & $\begin{array}{r}61.49 * * * \\
(0.21)\end{array}$ & $\begin{array}{c}0.43 \\
(0.41)\end{array}$ & $\begin{array}{c}-0.31 * * * \\
(0.03)\end{array}$ & $\begin{array}{r}0.83 * * \\
(0.41)\end{array}$ \\
\hline Leisure & $\begin{array}{r}29.57 * * * \\
(0.30)\end{array}$ & $\begin{array}{c}0.91 \\
(0.61)\end{array}$ & $\begin{array}{r}-0.38 \\
(0.04)\end{array}$ & $\begin{array}{r}1.23 * * \\
(0.01)\end{array}$ \\
\hline
\end{tabular}

Notes: ${ }^{1}$ According to the job loss dating of the recession, January 2003-December 2008 is the pre-recession period and January 2009-December 2010 is the recession period. The time use categories and the trend analysis categories (the column definitions) are identical to those used in the trend analysis with the NBER dating. 
Appendix Table 5 Trend analysis of the changes in time spent on unpaid work activities over the 2003-10 business cycle, job loss dating

\begin{tabular}{|c|c|c|c|c|}
\hline & (1) & (2) & (3) & (4) \\
\hline & $\begin{array}{c}\text { Observed prerecession } \\
\text { average }\end{array}$ & $\begin{array}{l}\text { Observed change } \\
\text { during recession }\end{array}$ & Trend effect & $\begin{array}{r}\text { Cycle effect } \\
(2)-(3) \\
\end{array}$ \\
\hline & \multicolumn{4}{|c|}{ Gap } \\
\hline Housework & $\begin{array}{l}9.98 * * * \\
(0.26)\end{array}$ & $\begin{array}{l}-0.94^{*} \\
(0.51)\end{array}$ & $\begin{array}{c}-0.67 * * * \\
(0.06)\end{array}$ & $\begin{array}{l}-0.24 \\
(0.51)\end{array}$ \\
\hline Child care & $\begin{array}{c}7.57 * * * \\
(0.25)\end{array}$ & $\begin{array}{l}-0.40 \\
(0.50)\end{array}$ & $\begin{array}{c}-0.63 * * * \\
(0.08)\end{array}$ & $\begin{array}{c}0.23 \\
(0.49)\end{array}$ \\
\hline Adult care & $\begin{array}{l}-0.06 \\
(0.09)\end{array}$ & $\begin{array}{l}-0.08 \\
(0.18)\end{array}$ & $\begin{array}{c}-0.22 * * * \\
(0.02)\end{array}$ & $\begin{array}{c}0.14 \\
(0.18)\end{array}$ \\
\hline \multirow[t]{2}{*}{ Shopping } & $\begin{array}{c}2.48 * * * \\
(0.15)\end{array}$ & $\begin{array}{l}-0.45 \\
(0.31)\end{array}$ & $\begin{array}{c}0.20 * * * \\
(0.02)\end{array}$ & $\begin{array}{r}-0.66 * * \\
(0.30)\end{array}$ \\
\hline & \multicolumn{4}{|c|}{ Mothers } \\
\hline Housework & $\begin{array}{l}19.72 * * * \\
(0.22)\end{array}$ & $\begin{array}{l}-0.91 * * \\
(0.43)\end{array}$ & $\begin{array}{c}-0.86^{* * *} \\
(0.08)\end{array}$ & $\begin{array}{c}0.05 \\
(0.43)\end{array}$ \\
\hline Child care & $\begin{array}{l}14.40 * * * \\
(0.21)\end{array}$ & $\begin{array}{c}0.27 \\
(0.42)\end{array}$ & $\begin{array}{c}-0.02 * * * \\
(0.00)\end{array}$ & $\begin{array}{c}0.28 \\
(0.42)\end{array}$ \\
\hline Adult care & $\begin{array}{l}1.02 * * * \\
(0.05)\end{array}$ & $\begin{array}{l}-0.09 \\
(0.11)\end{array}$ & $\begin{array}{c}-0.38 * * * \\
(0.03)\end{array}$ & $\begin{array}{r}0.28 * * * \\
(0.10)\end{array}$ \\
\hline Shopping & $\begin{array}{c}7.04 * * * \\
(0.14)\end{array}$ & $\begin{array}{c}-0.86 * * * \\
(0.28)\end{array}$ & $\begin{array}{c}-0.34 * * * \\
(0.03)\end{array}$ & $\begin{array}{r}-0.52 * \\
(0.28)\end{array}$ \\
\hline & \multicolumn{4}{|c|}{ Fathers } \\
\hline Housework & $\begin{array}{l}9.94 * * * \\
(0.20)\end{array}$ & $\begin{array}{l}-0.03 \\
(0.40)\end{array}$ & $\begin{array}{c}-0.16 * * * \\
(0.01)\end{array}$ & $\begin{array}{c}0.19 \\
(0.40)\end{array}$ \\
\hline Child care & $\begin{array}{c}6.83 * * * \\
(0.17)\end{array}$ & $\begin{array}{c}0.61 * * * \\
(0.06)\end{array}$ & $\begin{array}{c}0.56 * * * \\
(0.05)\end{array}$ & $\begin{array}{c}0.06 \\
(0.35)\end{array}$ \\
\hline Adult care & $\begin{array}{l}1.08 * * * \\
(0.07)\end{array}$ & $\begin{array}{l}-0.02 \\
(0.14)\end{array}$ & $\begin{array}{c}-0.16 * * * \\
(0.01)\end{array}$ & $\begin{array}{c}0.14 \\
(0.14)\end{array}$ \\
\hline Shopping & $\begin{array}{c}4.55^{* * * *} \\
(0.12)\end{array}$ & $\begin{array}{l}-0.40^{*} \\
(0.23)\end{array}$ & $\begin{array}{c}-0.54 * * * \\
(0.05)\end{array}$ & $\begin{array}{c}0.14 \\
(0.23)\end{array}$ \\
\hline
\end{tabular}

Notes: See notes to Appendix Table 4. The unpaid work time use categories are identical to those used in the trend analysis with the NBER dating. 
Appendix Table 6 Trend analysis of the time spent on paid, unpaid and total work by full time employed mothers and fathers over the 2003-10 business cycle, NBER dating

\begin{tabular}{|c|c|c|c|c|c|c|c|c|c|c|}
\hline & (1) & (2) & (3) & (4) & (5) & (6) & (7) & (8) & (9) & $(10)$ \\
\hline & $\begin{array}{c}\text { Observed } \\
\text { prerecession } \\
\text { average }\end{array}$ & $\begin{array}{l}\text { Observed } \\
\text { change during } \\
\text { recession }\end{array}$ & $\begin{array}{l}\text { Trend } \\
\text { effect }\end{array}$ & $\begin{array}{c}\text { Cycle effect: } \\
\text { Recession }\end{array}$ & $\begin{array}{c}\text { Observed } \\
\text { change during } \\
\text { extended } \\
\text { unemployment }\end{array}$ & $\begin{array}{l}\text { Trend effect } \\
\text { during } \\
\text { extended } \\
\text { unemployment }\end{array}$ & $\begin{array}{l}\text { Cycle effect: } \\
\text { Extended } \\
\text { unemployment }\end{array}$ & $\begin{array}{c}\text { Observed } \\
\text { change (Dec. } \\
2007- \\
\text { Dec.2010) }\end{array}$ & $\begin{array}{l}\text { Trend effect } \\
\text { (Dec. 2007- } \\
\text { Dec. 2010) }\end{array}$ & $\begin{array}{l}\text { Cycle effect } \\
\text { (Dec. 2007- } \\
\text { Dec. 2010) }\end{array}$ \\
\hline & \multicolumn{10}{|c|}{ Gap (Mothers- Fathers) } \\
\hline $\begin{array}{l}\text { Paid } \\
\text { work }\end{array}$ & $\begin{array}{r}-6.80 * * * \\
(0.72)\end{array}$ & $\begin{array}{l}1.03 \\
(1.45)\end{array}$ & $\begin{array}{c}-0.78 * * * \\
(0.07)\end{array}$ & $\begin{array}{l}1.81 \\
(1.45)\end{array}$ & $\begin{array}{l}-0.24 \\
(1.85)\end{array}$ & $(0.04)^{-0.37 * * *}$ & $\begin{array}{l}0.13 \\
(1.85)\end{array}$ & $\begin{array}{l}0.79 \\
(1.48)\end{array}$ & $\begin{array}{l}-1.15^{* * * *} \\
(0.08)\end{array}$ & 1.93 \\
\hline Unpaid & $10.26 * * *$ & -0.64 & $-0.18 * * *$ & -0.46 & 1.37 & $-0.08 * * *$ & 1.45 & 0.73 & $-0.26 * * *$ & 0.99 \\
\hline work & $(0.49)$ & $(0.98)$ & $(0.02)$ & $(0.98)$ & $(1.28)$ & $(0.01)$ & $(1.28)$ & $(1.00)$ & $(0.02)$ & $(1.00)$ \\
\hline Total & $3.46^{* * *}$ & 0.39 & $-0.95 * * *$ & 1.35 & 1.13 & $-0.45 * * *$ & 1.58 & 1.52 & $-1.41 * * *$ & $2.93 * *$ \\
\hline \multirow[t]{2}{*}{ work } & $(0.58)$ & $(1.17)$ & $(0.09)$ & $(1.17)$ & $(1.60)$ & $(0.04)$ & $(1.60)$ & $(1.19)$ & $(0.09)$ & $(1.19)$ \\
\hline & \multicolumn{10}{|c|}{ Mothers } \\
\hline Paid & $39.81 * * *$ & 0.86 & $-0.53 * * *$ & 1.39 & -0.67 & $-0.25 * * *$ & -0.42 & 0.20 & $-0.78 * * *$ & 0.97 \\
\hline work & $(0.57)$ & (1.16) & $(0.05)$ & (1.16) & (1.41) & $(0.02)$ & (1.42) & (1.18) & $(0.05)$ & (1.19) \\
\hline Unpaid & $31.49 * * *$ & -1.01 & $-0.01 * * *$ & -1.00 & 1.07 & $0.00 * * *$ & 1.08 & 0.06 & $-0.01 * * *$ & 0.07 \\
\hline work & $(0.38)$ & $(0.77)$ & $(0.00)$ & $(0.77)$ & (0.99) & $(0.00)$ & (0.99) & $(0.79)$ & $(0.00)$ & $(0.79)$ \\
\hline Total & $71.30 * * *$ & -0.15 & $-0.53 * * *$ & 0.39 & 0.41 & $-0.25 * * *$ & 0.66 & 0.26 & $-0.79 * * *$ & 1.05 \\
\hline \multirow[t]{2}{*}{ work } & $(0.50)$ & $(1.01)$ & $(0.05)$ & $(1.01)$ & $(1.26)$ & $(0.03)$ & $(1.27)$ & $(1.03)$ & $(0.05)$ & $(1.04)$ \\
\hline & \multicolumn{10}{|c|}{ Fathers } \\
\hline Paid & $46.61 * * *$ & -0.17 & $0.25 * * *$ & -0.42 & -0.42 & $0.12 * * *$ & -0.54 & -0.59 & $0.37 * * *$ & -0.96 \\
\hline work & $(0.51)$ & (1.02) & $(0.02)$ & (1.02) & $(1.32)$ & $(0.01)$ & $(1.32)$ & $(1.05)$ & $(0.02)$ & (1.04) \\
\hline Unpaid & $21.23 * * *$ & -0.37 & $0.17 * * *$ & -0.54 & -0.30 & $0.08 * * *$ & -0.38 & -0.67 & $0.25 * * *$ & -0.92 \\
\hline work & $(0.32)$ & $(0.65)$ & $(0.02)$ & $(0.65)$ & $(0.91)$ & $(0.01)$ & $(0.91)$ & $(0.67)$ & $(0.02)$ & $(0.67)$ \\
\hline Total & $67.84 * * *$ & -0.54 & $0.42 * * *$ & -0.96 & -0.72 & $0.20 * * *$ & -0.92 & -1.26 & $0.62 * * *$ & $-1.88 * *$ \\
\hline work & $(0.41)$ & $(0.82)$ & $(0.04)$ & $(0.82)$ & (1.09) & $(0.02)$ & (1.09) & $(0.84)$ & $(0.04)$ & $(0.84)$ \\
\hline
\end{tabular}

Notes: The sample consists of 10,545 mothers and 6,069 fathers. See notes to Table 3. 
Appendix Table 7 Estimated changes in gender differences in weekly work hours over the course of 2003-10 with demographic controls

\begin{tabular}{lcc}
\hline & & Extended unemployment- \\
& Recession-Prerecession & Prerecession \\
\hline \multirow{2}{*}{ Paid work } & $2.80^{*}$ & $5.20^{* * *}$ \\
& $(1.65)$ & $(1.84)$ \\
Unpaid work & $-2.58^{* *}$ & $-2.73^{* *}$ \\
& $(1.06)$ & $(1.13)$ \\
Total work & 0.55 & $3.03^{* *}$ \\
\hline
\end{tabular}

Notes: Standard errors are in parentheses. $* * *, * *, *$ denote statistical significance at the 1,5 , and 10 percent

levels. The first column presents the conditional difference in the gender gap (mothers-fathers) in weekly hours of paid, unpaid, and total work hours, between the recession and the pre-recession periods. The second column presents the coefficient on the extended unemployment period dummy variable. 